\title{
DECORATED MEDIEVAL OR EARLY MODERN AXES FROM THE NATIONAL MUSEUM OF ROMANIAN HISTORY IN BUCHAREST
}

\author{
Martin Husár - Silviu Ion Oța - Tudor Alexandru Martin
}

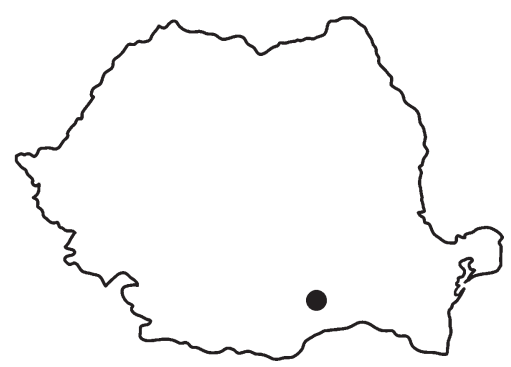

DOI: https://doi.org/10.31577/szausav.2019.66.7

Keywords: decoration, axes, axe heads, High and Late Middle Ages, Early Modern Period, National Museum of Romanian History, Bucharest, Romania

\begin{abstract}
The authors of the article deal with three axe heads and one complete axe from the National Museum of Romanian History in Romania, which can be dated from the end of the High Middle Ages to the Early Modern Period. The museum received these objects to its depositories between the year 1975 and 2015. Their mutual feature is that they were decorated and have not been assessed yet in regard to their shape or decoration. This decoration concerns mostly form in the case of axe with inv. no. 37793. Its head has got the openwork cheek and blade ( 9 holes), where 6 concave cuts are present as well. Moreover, there are 10 probable nails made of yellow non-ferrous metal in its handle and one maker's mark on its neck that probably comprises a lime tree leaf and branch. Other three axe heads have got punched decoration. The decoration of the exemplar from Balta Neagră (donation no. 1555) mainly consist of lines, circles, cogged curves and their combinations. Then the specimen from Fântâna Mare (inv. no. 178595) was lavishly embellished by patterns made of cogged lines and on the axe head from Suceava (inv. no. 72492) a punched quatrefoil was only applied.
\end{abstract}

\section{INTRODUCTION}

The article is focused on three decorated axe heads and one axe from the National Museum of Romanian History in Bucharest, Romania/Muzeul Național de Istorie a României, București, România (MNIR), which can be dated at the turn of the Middle Ages and Modern Period (Table 1). We exactly mean a period of time between the end of High Middle Ages and the Early Modern Period. The examined objects are indexed in the MNIR by the following inv. no. - 37793, 72492, 178595 - and one donation no. -1555 . Two of them were discovered in the Suceava County within Romanian Bukovina and Moldova - axe heads from Fântâna Mare (inv. no. 178595) and Suceava (inv. no. 72492), one in the Ilfov County within Wallachia - axe head from Balta Neagră (donation no. 1555), and the last is housed at the MNIR without the specification of its archaeological/find context under inv. no. 37793 (Fig. 1). Each above mentioned exemplar has got the particular shape and decoration. Except from the axe head from Fântâna Mare (Bătrîna/Monoranu/Bătrîna 1984, 172, fig. 5: 1), the rest of the examined assemblage have not been published yet. However, the exemplar from Fântâna Mare has not been evaluated in relation to its decoration and form too.

\section{LINES, CIRCLES, AND COGGED CURVES}

In January 2015 one stray find of an axe head (Fig. 2: 1) was unearthed from an unknown forest near the village Balta Neagră in the Nuci commune. Then it was transferred to the MNIR and registered there under donation no. 1555.

The iron broad axe head has got the prolonged beard, which is projected downwards in profile. The blade is fitted with a distinct spike projecting upwards. The most of the eye is missing there and just the shapeless part of it remained. The beard has probably been bevelled at its end. One side of the axe head is decorated by punched ornaments. First, there are lines and circles that stand alone or are connected 


\begin{tabular}{|c|c|c|c|c|c|}
\hline \multicolumn{2}{|c|}{ 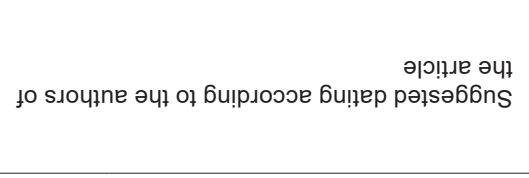 } & 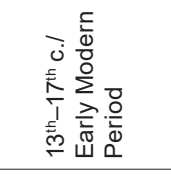 & $\begin{array}{l}0 \\
\text { 芒 } \\
\stackrel{5}{\leftarrow}\end{array}$ & 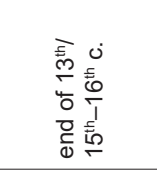 & 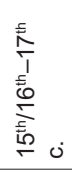 \\
\hline \multicolumn{2}{|r|}{ 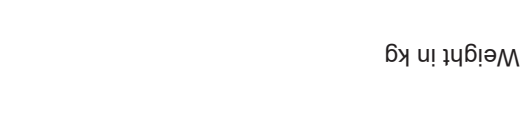 } & 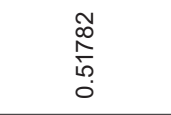 & $\begin{array}{l}\stackrel{L}{0} \\
\stackrel{0}{+1} \\
\stackrel{+}{+}\end{array}$ & \begin{tabular}{l}
0 \\
\multirow{N}{W}{} \\
$\infty$ \\
0 \\
0
\end{tabular} & $\stackrel{\bar{g}}{\stackrel{\leftrightarrow}{r}}$ \\
\hline \multirow{8}{*}{ 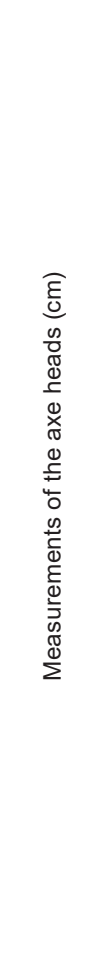 } & 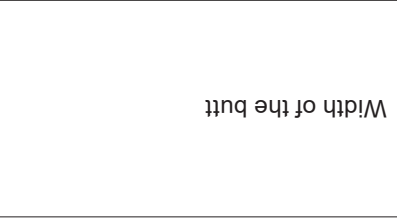 & 1 & 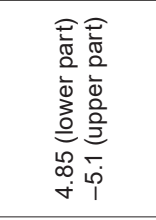 & 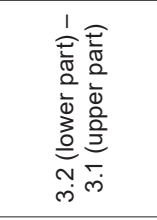 & 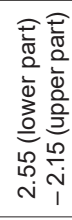 \\
\hline & 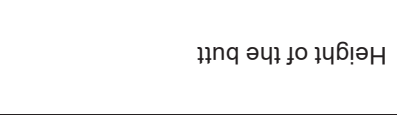 & 1 & 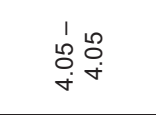 & $\nabla$ & $\begin{array}{l}L \\
0 \\
1 \\
10 \\
0 \\
0\end{array}$ \\
\hline & әરә ә૫૫ ł૦ Чұр!М & 1 & 1 & $\stackrel{\mathscr{\rho}}{\infty}$ & I \\
\hline & 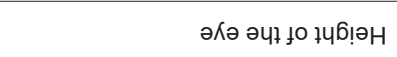 & 1 & 1 & 1 & $\stackrel{\text { L }}{\stackrel{2}{\rightleftarrows}}$ \\
\hline & 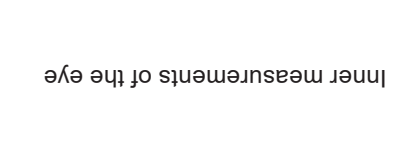 & 1 & 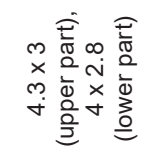 & 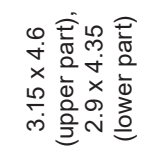 & 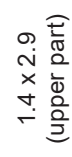 \\
\hline & 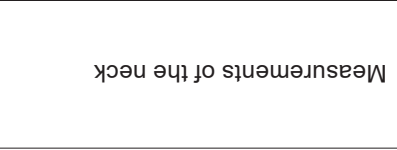 & $\begin{array}{l}\mathfrak{r} \\
\dot{x} \\
\llcorner \\
\varrho \\
\dot{N}\end{array}$ & 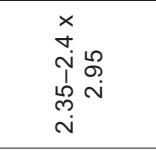 & $\begin{array}{l}\stackrel{\infty}{\sim} \\
\underset{\sim}{x} \\
\infty \\
\stackrel{N}{N}\end{array}$ & $\begin{array}{l}1 \\
0 \\
0 \\
0 \\
\times \\
0 \\
i \\
i\end{array}$ \\
\hline & әре|q әчұ ґо чұбиәา & 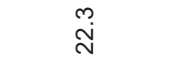 & ^ & $\stackrel{\mathscr{N}}{\sim}$ & $\stackrel{\infty}{\leftarrow}$ \\
\hline & 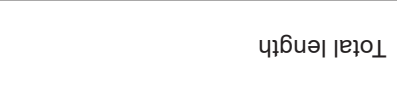 & $\stackrel{\stackrel{L}{m}}{\stackrel{2}{m}}$ & 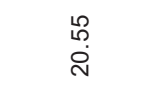 & $\stackrel{\infty}{\stackrel{\odot}{\leftarrow}}$ & $\stackrel{m}{\stackrel{\infty}{\circ}}$ \\
\hline \multirow{3}{*}{ 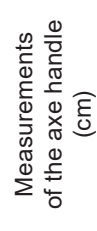 } & 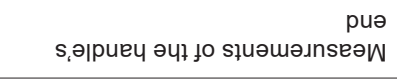 & 1 & 1 & 1 & 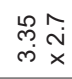 \\
\hline & 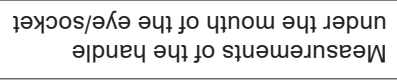 & 1 & 1 & 1 & 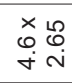 \\
\hline & 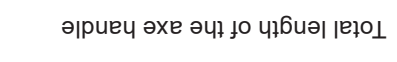 & । & । & । & $\hat{\mathscr{H}}$ \\
\hline \multirow{2}{*}{\multicolumn{2}{|c|}{ 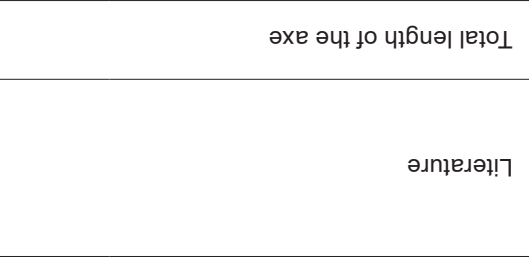 }} & 1 & 1 & 1 & $\frac{0}{\dot{0}}$ \\
\hline & & 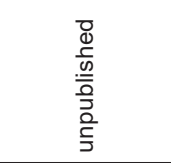 & 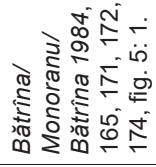 & $\begin{array}{l}\frac{0}{0} \\
\frac{0}{0.0} \\
\frac{0}{0} \\
\frac{0}{0} \\
\frac{0}{5}\end{array}$ & 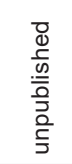 \\
\hline \multirow{2}{*}{\multicolumn{2}{|c|}{ ұхәңиоо риу//еэ!борооәечэл }} & n & $\ddot{\theta}$ & $\check{\infty}$ & 운 \\
\hline & & 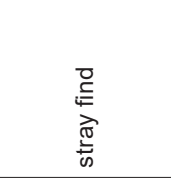 & 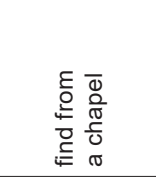 & 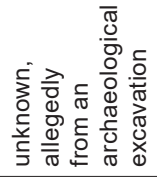 & 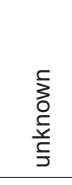 \\
\hline \multicolumn{2}{|r|}{ 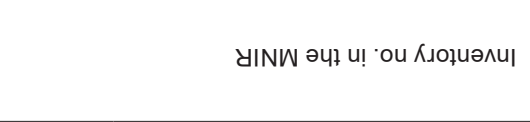 } & 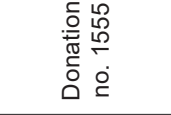 & 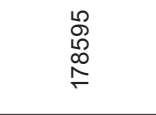 & 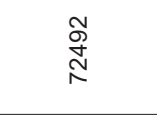 & 㣻 \\
\hline \multicolumn{2}{|r|}{ ә¥! } & 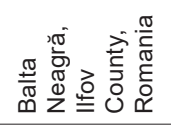 & 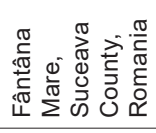 & 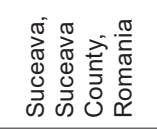 & 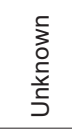 \\
\hline & ON & - & N & $m$ & $\diamond$ \\
\hline
\end{tabular}




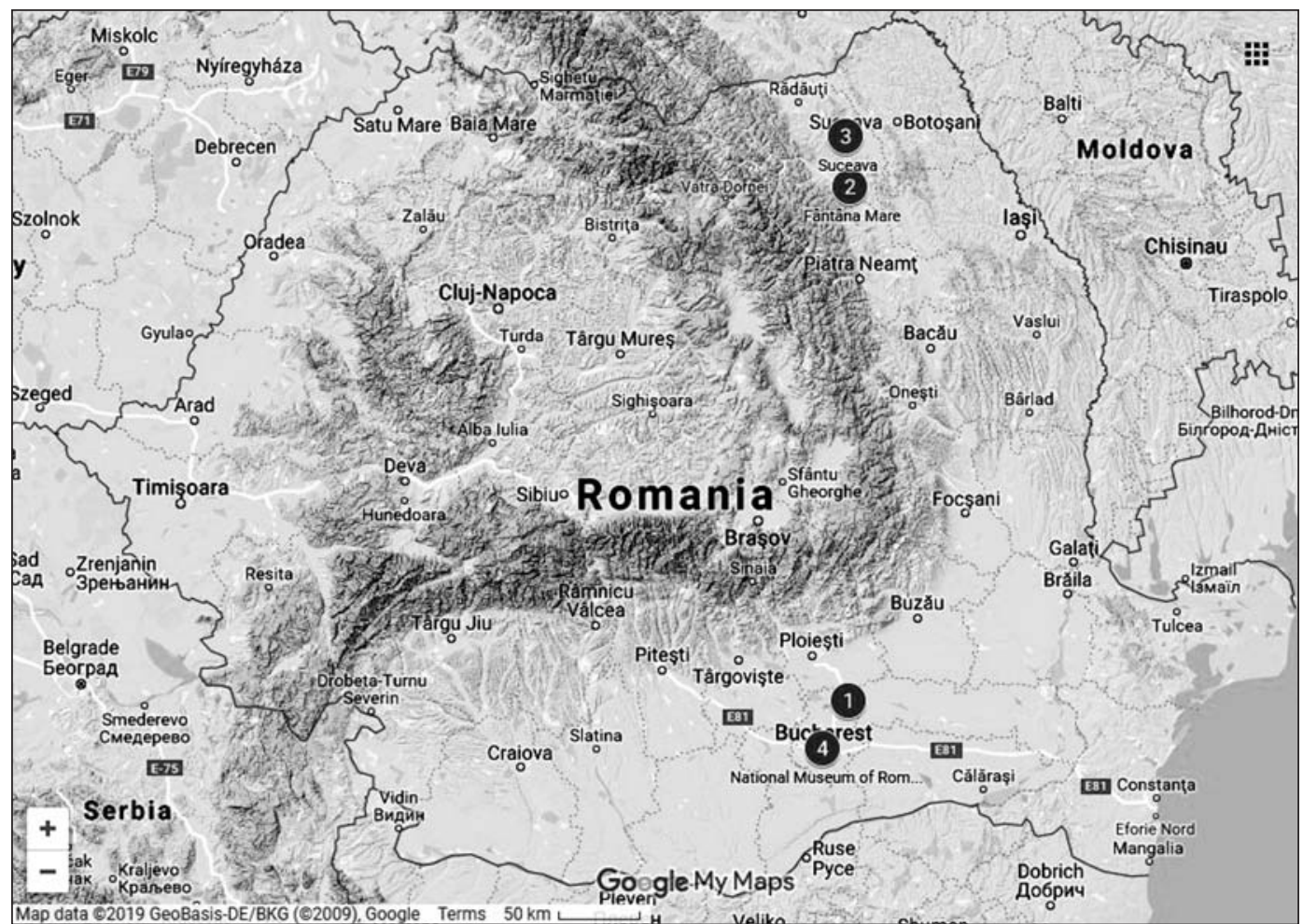

Fig. 1. Sites where decorated medieval or early modern axes from the National Museum of Romanian History in Bucharest (RO) were found. 1 - Balta Neagră (Ilfov County, RO), donation no. 1555 in the MNIR; 2 - Fântâna Mare (Suceava County, RO), inv. no. 178595 in the MNIR; 3 - Suceava (Suceava County, RO), inv. no. 72492 in the MNIR; 4 - unknown site/National Museum of Romanian History in Bucharest, inv. no. 37793. Author of the distribution map: M. Husár. Map source: Google My Maps.

together and form various patterns, which resemble the letter X (made of four punched lines), rhomboid, sun-like motif, branchlet (three radially converging lines with circles at their ends), and curves. Then there are also punched relatively short bent curves/sickles that are cogged (15 or 16 pieces). In this case punched curves with small semicircles are concerned that project to their one side. They are mainly punched on the edges of the blade, first at foremost, on the edges of the beard, although two of them are between the cheek and blade. The neck of the axe head is rectangular in cross-section. Finally, the referred axe head is asymmetric in cross-section from above or below and the cutting edge of the blade tapers asymmetrically as well.

As far as analogies in relation to the form of the blade, cheek and neck of the referred axe head in profile are concerned, we might also reckon its early or high medieval origin. Some of these parallels are decorated, but they and other contemporary axe heads do not match the decoration of the referred axe head. ${ }^{1}$ The analogies are symmetric from above or below, fitted with pointed lugs and mainly with a butt. The referred axe head misses these features and the last two ones cannot anyhow be checked here

1 It seems that the punched ornaments from Northern, Central, and Eastern Europe and partially from Southeastern Europe between the $9^{\text {th }}$ and $12^{\text {th }} / 13^{\text {th }}$ centuries did not resemble the decoration of the discussed axe head from Balta Neagră. The decoration of the $9^{\text {th }}-13^{\text {th }}$ century axe heads from Poland contains punched lines and curves that form various quite simple patterns, including crosses and branchlets. Branchlets on the axe head from the fortified settlement of Barkowice Mokre (the middle of the $9^{\text {th }}$ century) were made of one quite long line and many converging lines into this main one. Also there were not circles within these branchlets (Kotowicz 2011, 107, fig 2: 1). Then we know that the letter X pattern, which is present (in the form of lines) upon the referred axe head from Balta Neagră, can be seen on the blade of the axe head from Alm Østre (Norway; the $10^{\text {th }}$ century) in the different form. The pattern comprises punched dots or dots in the form of pointillé decoration (Kotowicz 2013, 43, fig. 2: 2). Also the punched ornaments of the axe head from Balta Neagră are not present on the surfaces of the miniature axe heads from Northern, Central, Eastern Europe as well as parts of Southeastern Europe from the second quarter of the $11^{\text {th }}$ century to the end of the $12^{\text {th }}$ century (Kucypera/Pranke/Wadyl 2010, 121, 122), although there are various combinations of lines, circles, dots, and curves (Kucypera/Pranke/Wadyl 2010, 103-176; Kucypera/Wadyl 2011, 122-130). Zig-zag patterns were also popular there. 


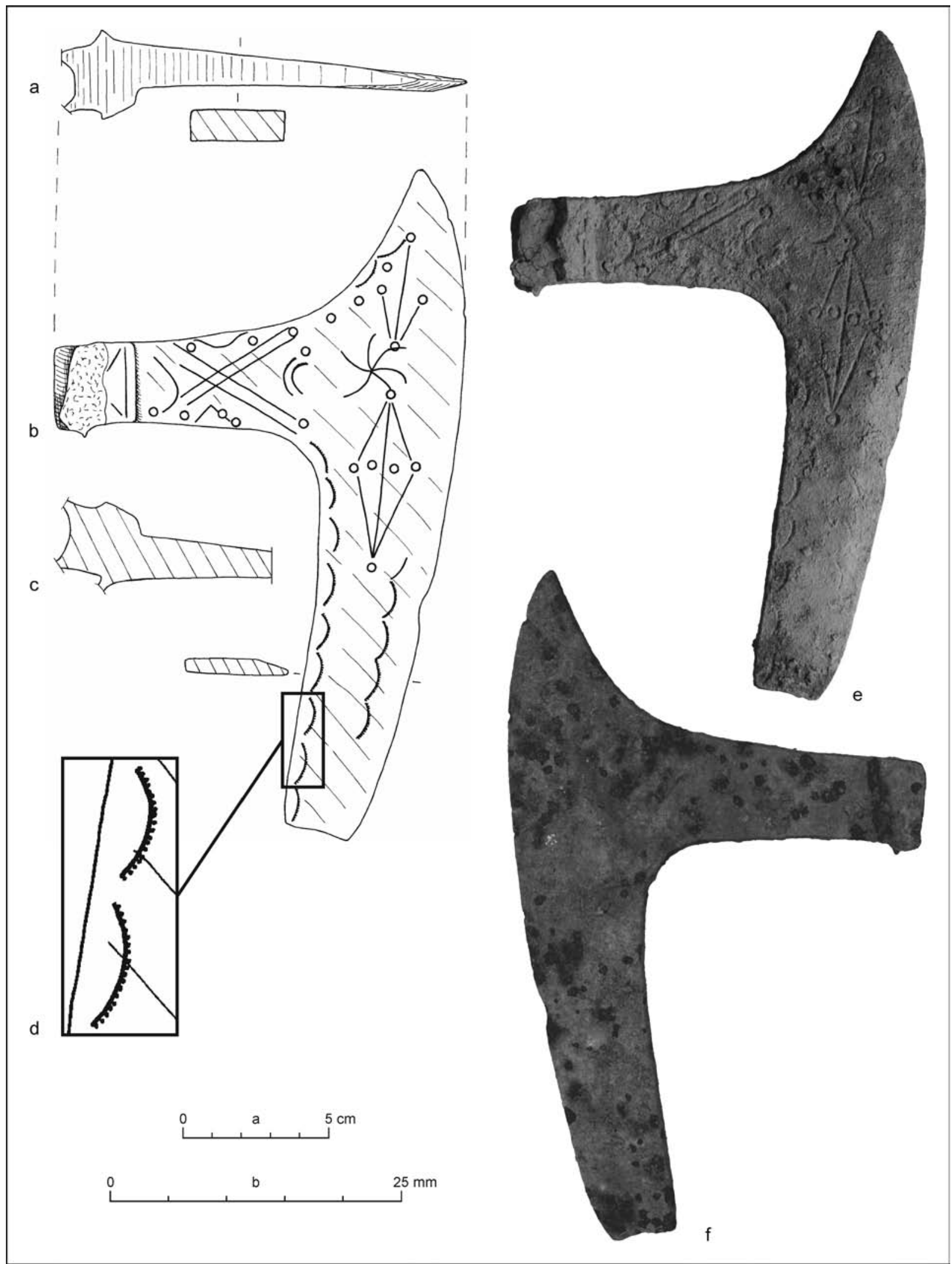

Fig. 2. Examined axe head from Balta Neagră (Ilfov County, RO, stray find, donation no. 1555 , the $13^{\text {th }}$ century-the $17^{\text {th }}$ century/Early Modern Period) deposited in the National Museum of Romanian History in Bucharest (RO). a-d - drawings by G. Ducman; e - photograph by T. A. Martin; $\mathrm{f}$ - photograph by M. Husár. All iron. Scale: $\mathrm{a}-\mathrm{a}-\mathrm{c}, \mathrm{e}-\mathrm{f} ; \mathrm{b}-\mathrm{d}$. 


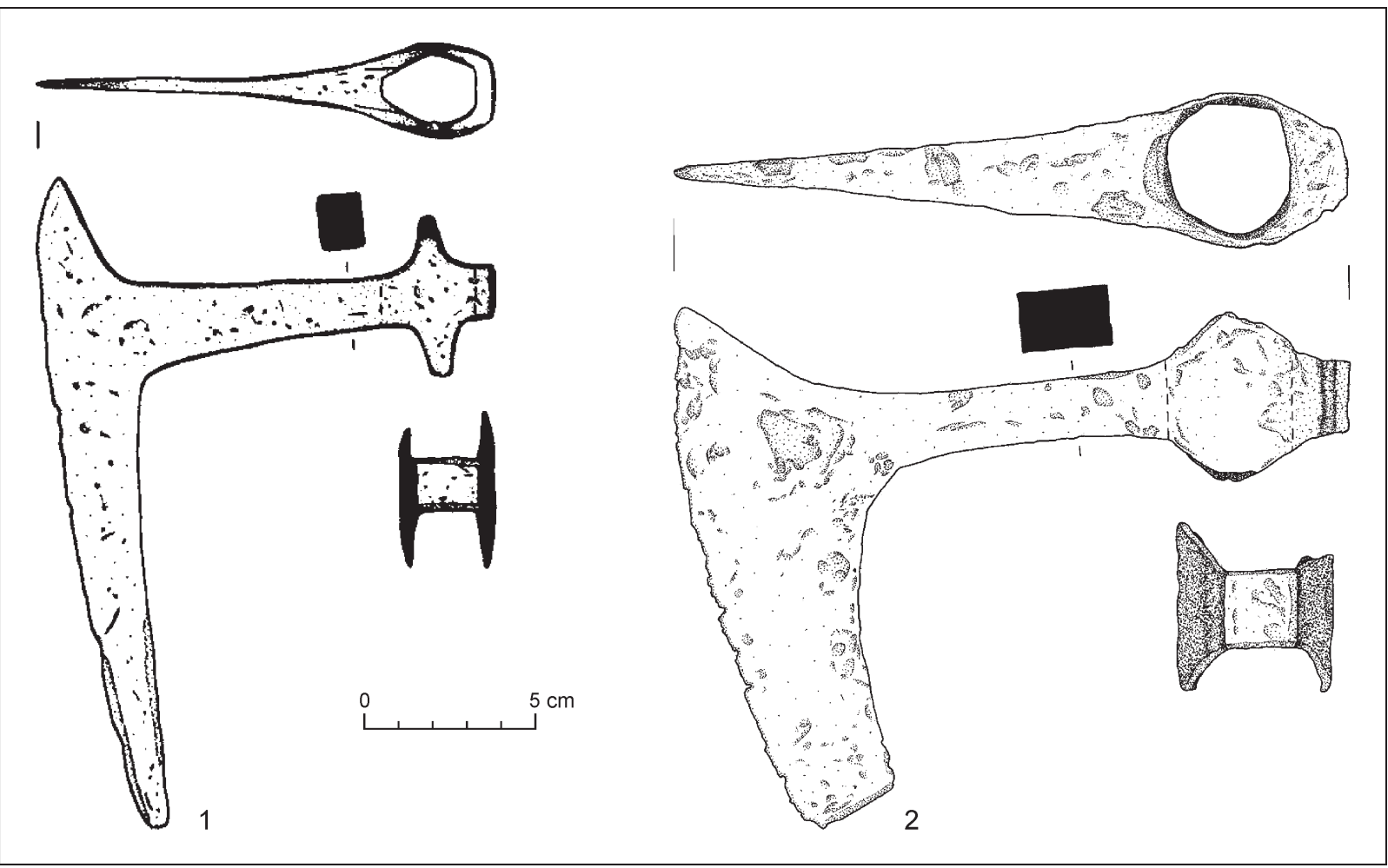

Fig. 3. Analogies for features of the examined medieval and early modern axe head from Balta Neagră (donation no. 1555) deposited in the National Museum of Romanian History in Bucharest (RO). 1 - Archaeological Museum in Cracow, the second half of the $10^{\text {th }}$ century and the first half of the $11^{\text {th }}$ century (according to the dating of the Lunow type of axe heads; PL, after Kotowicz 2011, fig. 5: 6; Michalak/Kotowicz 2014, 115, fig. 7: 6); 2 - National Museum in Szczecin, the second half of the $10^{\text {th }}$ century and the first half of the $11^{\text {th }}$ century (according to the dating of the Lunow type of axe heads; PL, after Kotowicz 2014, tab. CLXVII: 4; Michalak/Kotowicz 2014, 115, fig. 7: 8). All iron.

because of its damaged eye. However, if it had these three features, it would be named the Lunow type of axe heads, which is well known in scientific literature since 1991 thanks to Polish archaeologist M. Kara (more in Michalak/Kotowicz 2014, 110, 111). In 2014 A. Michalak and P. Kotowicz (2014, 107, 110-112, fig. 5-7) listed 22 exemplars (e.g. Fig. 3: 1-2) found in Denmark, Germany, Poland, Russia (just in the Kaliningrad Region/Калинингра́дская оббласть), and Sweden, which are mostly dated to the second half of the $10^{\text {th }}$ century and the first half of the $11^{\text {th }}$ century. P. Kotowicz $(2014,62,104,184,185,190,194,206,212$, nr. kat. 213, 400, 732, 735, 763, 776, 837, 868; tab. XXXIV: 2; LXV: 2; CXXXIX: 2, 5; CXLIII: 2; CXLV: 1; CLIX: 3; CLXVII: 4) ${ }^{2}$, A. Nadolski (1954, 43, tab. XV) ${ }^{3}$, and A. Pedersen (2002, 30, 31, fig. II-6; 2014a; 2014b, 28, 33, cat. no. 61, 118, 229; pl. 4: 1; 11: 3; 33: 2$)^{4}$ more or less support this time span in their monographs and studies concerning Poland and Denmark as well. Two Lunow type exemplars from Eastern Germany were published by I. Heindel (1992, 41, fig. 21: $\mathrm{f}-\mathrm{g}$ ), who suggested to date them since the $10^{\text {th }}$ century or the middle of the $11^{\text {th }}$ century with the possibility of continuation of this form up to the $13^{\text {th }}$ century. There is also one similar exemplar from present-day Bulgaria and other one from the same country, which has a quite longer butt in comparison with the aforementioned specimens. Both of them (Jotov 2004, каталог no. 584, 588, табло L: 584; LI: 588) are from settlement sites (Борован аnd Люти брод) identically dated to the $9^{\text {th }}-11^{\text {th }}$ centuries.

There is little doubt that the asymmetric shape of the examined axe head from above or below and its punched decoration point to the High/Late Middle Ages and Early Modern Period in Europe. Many European axe heads as well as heads of other weapons and tools of various forms from the end of the

2 These exemplars are dated to the second half of the $10^{\text {th }}$ century and the $11^{\text {th }}$ century.

3 These specimens are within A. Nadolski's type III that belongs to the $11^{\text {th }}$ century.

4 The axe heads can be dated circa between $10^{\text {th }}$ century and first half of the $11^{\text {th }}$ century. A. Pedersen $(2002,31)$ assumed that the provenance of this form of axe heads is in the southeastern and southern Baltic region. 


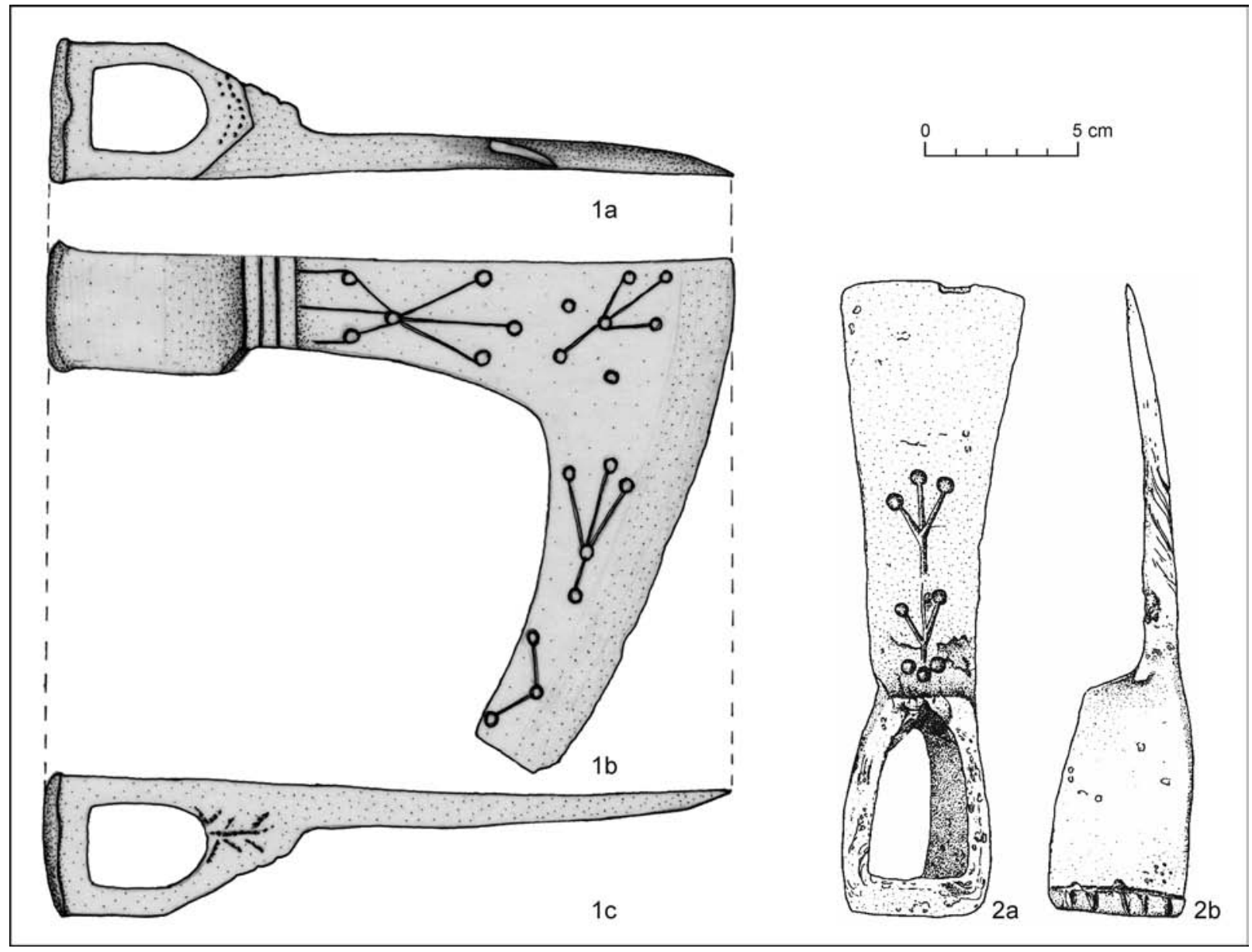

Fig. 4. Analogies for features of the examined medieval and early modern axe head from Balta Neagră (donation no. 1555) deposited in the National Museum of Romanian History in Bucharest (RO). 1 - Valea Mărului, stray find, after the middle of the second millennium AD (Galați County, RO; after Croitoru 2016, 337, fig. 4: 1); 2 - Konůvky, fortress, up to the first half of the $15^{\text {th }}$ century (CZ, after Měchurová 2013, 627, fig. 5). All iron.

Middle Ages and the beginning of the Modern Period have got varied punched decoration. ${ }^{5}$ These objects are of different forms from the referred axe head, but their decoration also consists of combined lines and dots/circles/half-moons that are mostly in the shape of a branchlet or three radially converging lines with dots/circles/half-moons at their ends. In several cases, makers' marks were punched there too.

When it comes to the aforementioned punched branchlets, they can be observed on several specimens found or deposited in today's Romania, Poland, and the Czech Republic. The axe head from Valea Mărului (Fig. 4: 1; stray find) looks roughly similar to the axe head from Balta Neagră (Croitoru 2016, 337, Fig. 4), though it misses a distinct spike projecting upwards. C. Croitoru (2016, 337, fig. 4) broadly dated this specimen to the time after the middle of the second millennium AD. It has got, inter alia, the punched decoration of one side of its head that comprises lines and circles. Their combinations create three or four branchlets and other patterns. Two other axe heads housed in two Romanian museums were also embellished by branchlets, which consist of three radially converging lines with circles at their ends. To begin with, the pickaxe/axe head from house L 11 (section S III) in the settlement of Curtea Domnească de la Vaslui (Fig. 5: 1; Dejan/Ilie 2017, 113, figure on page 113; Ilie/Dejan 2018, 197, figure on page

5 The punched decoration of pole and hitting weapons from present-day Poland and the Czech Republic, which includes various lines, curves, circles, dots, rosettes, and their combinations (even in the form of branchlets), was dated by L. Marek $\left(2008,357\right.$, fig. 184: b, d-f) already to the $15^{\text {th }}$ century and it is obvious that this decoration continued to be applied at least next two centuries (Marek 2008, 128-130). Z. Měchurová claimed that punched decoration (dots, rosettes/flowers, arches, and lines) was not a precise time-sensitive element in relation to medieval and modern period axes. She stated that such decoration has endured from the second half of the $13^{\text {th }}$ century to the present (Měchurová 2013, 627, 628). 


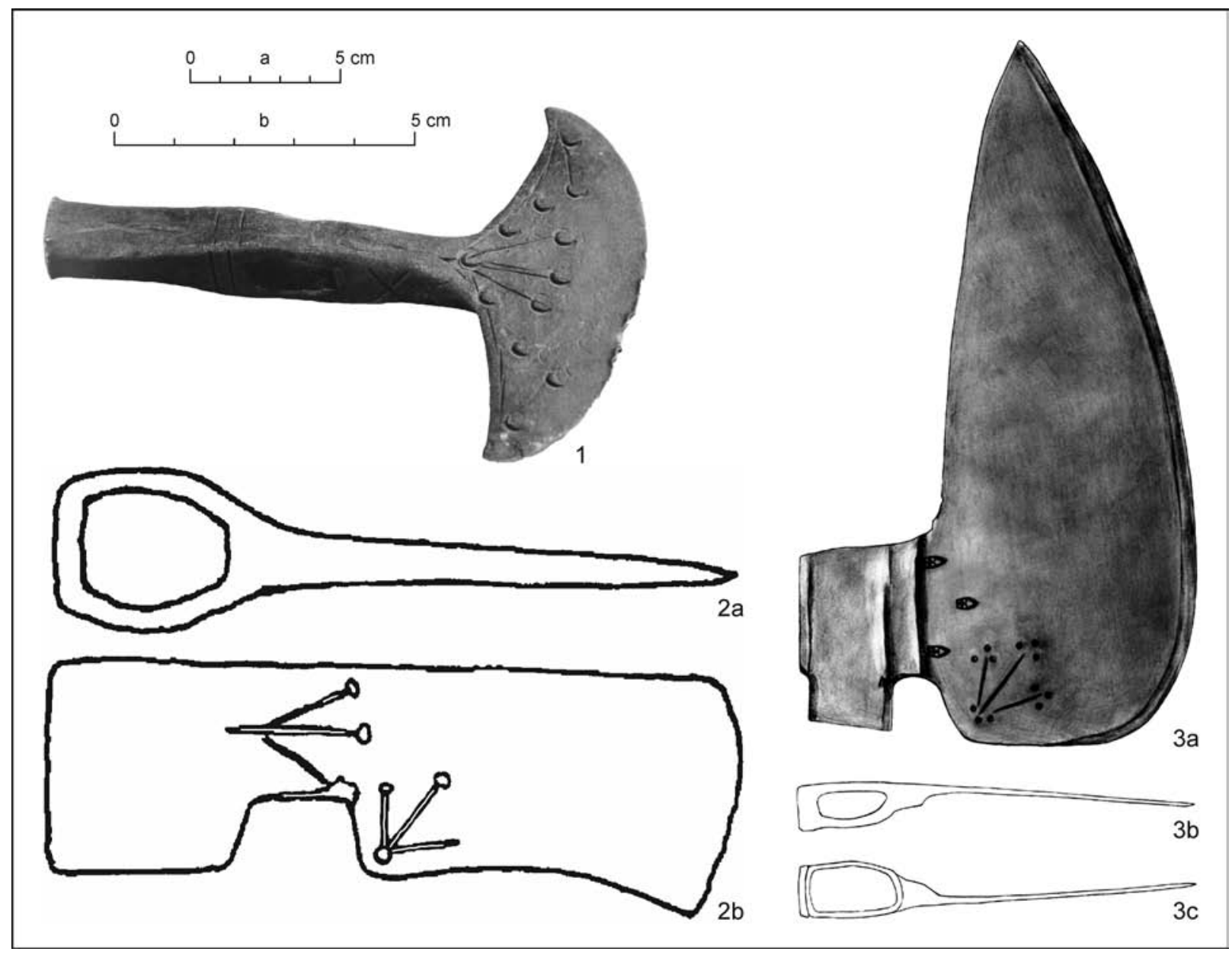

Fig. 5. Analogies for features of the examined medieval and early modern axe head from Balta Neagră (donation no. 1555) deposited in the National Museum of Romanian History in Bucharest (RO). 1 - Curtea Domnească de la Vas-

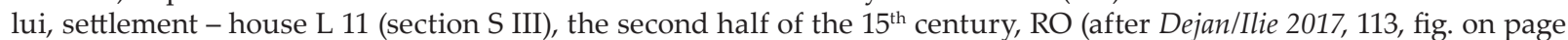
113; Ilie/Dejan 2018, 197, fig. on page 197); 2 - unknown site, not clear find context, the $13^{\text {th }}-16^{\text {th }}$ centuries? (after Gtosek 1996, 94, tab. XVI: C); 3 - Toszek, not clear find context, the $15^{\text {th }}-16^{\text {th }}$ centuries, possibly the $17^{\text {th }}$ century (PL; after Zdaniewicz 2016, 269, fig. 2-5). All iron. Scale: a - 1, 2; b-3.

197) belongs to this group. There are combinations of lines and circles on its blade and cheek, from which one complete branchlet grows. The neck of the head is decorated by punched decoration on its two sides, which contain lines and the letter $X$ patterns. The settlement of the above mentioned site, which is located in Romanian Moldova, can be dated to the second half of the $15^{\text {th }}$ century (Andronic/Popescu 1980, 127, 128). Secondly, the accidently found axe head, which is deposited in the County Museum Botoșani (Dejan/Ilie 2017, 112, figure on page 112; Ilie/Dejan 2018, 196, figure on page 196), was punched on its both sides by lines, relatively small and larger dots/circles, and their combinations that create branchlet patterns too. This head was dated between the $15^{\text {th }}$ and $17^{\text {th }}$ (?) centuries and S. Eduard deduced the beginning of its usage, i.e. in the $15^{\text {th }}$ century, from one spur discovered in the earthen fortress of Bârlad. This spur has got engraved or punched patterns in the form of the letter $\mathrm{X}$ and the given fortress was in operation during the second half of the $15^{\text {th }}$ century (Matei/Chițescu 2002, 13, 148, fig. 53). Then we can also count on Czech and Moravian finds in regard to the referred branchlet decorations. Combinations of punched lines and circles, which create branchlet patterns, are on exemplars (found out of context) from PrahaPodskalí, Praha and Poděbrady that are dated between the end of the $14^{\text {th }}$ century and the beginning of the $16^{\text {th }}$ century (Novotný 1956, 346, fig. 2; 8: 3, 4). The last two above mentioned axe heads from Praha and Poděbrady are fitted with branchlets in the serial order. The specimen from Praha-Podskalí was also stamped by a maker's mark (Novotný 1956, 346, fig. 2). The axe head from Hradišt'ko u Davle-Sekance has got one punched branchlet, which consists of three radially converging lines and four half-moons 


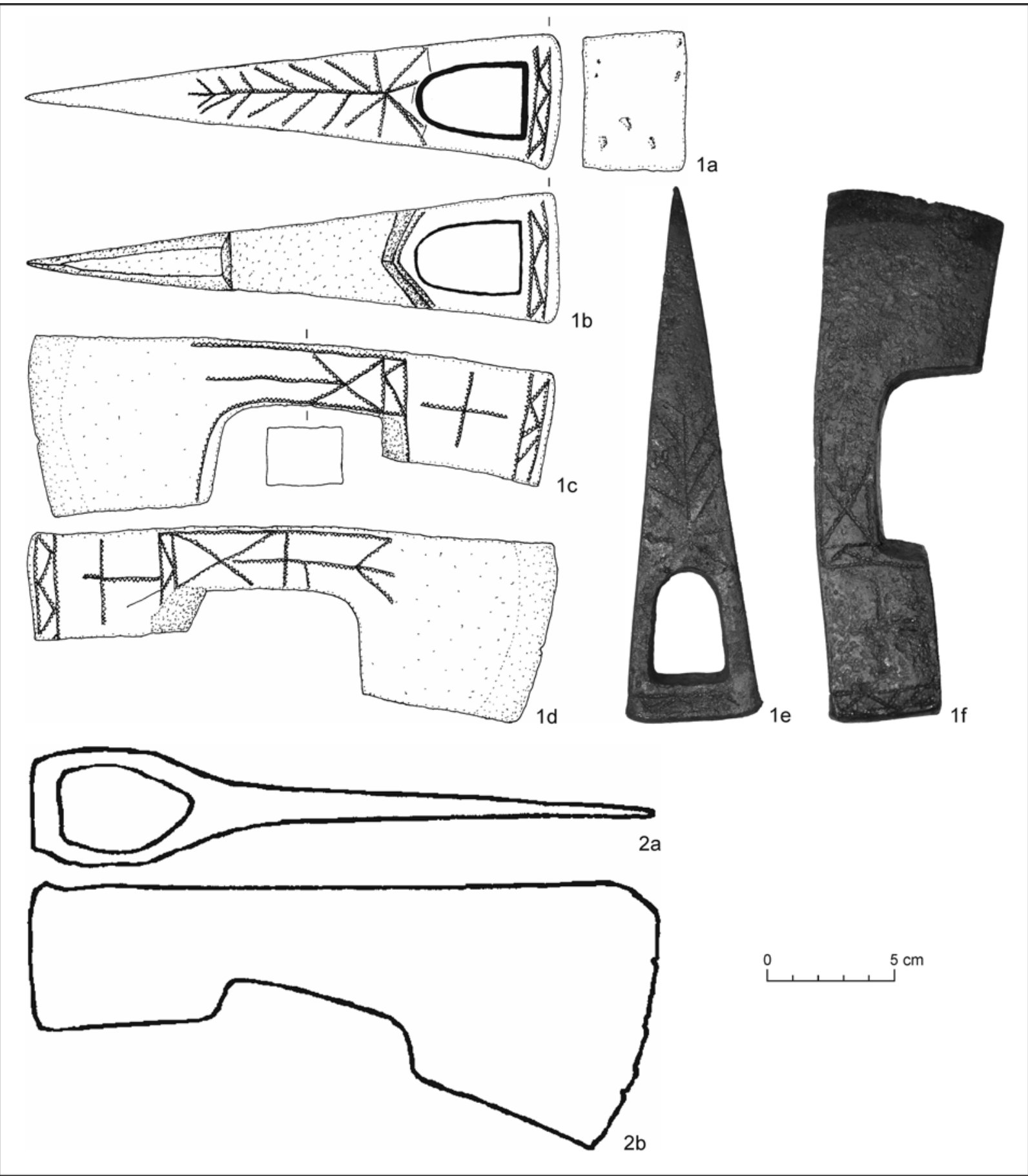

Fig. 6. Examined medieval and early modern axe head from Fântâna Mare (inv. no. 178595) deposited in the National Museum of Romanian History in Bucharest (RO) and analogy for its features. 1 - Fântâna Mare, stray find from the area of the chapel, the $15^{\text {th }}$ century (Suceava County, RO; inv. no. 178595 in the MNIR; drawings and photographs by M. Husár); 2 - Radymno, aquatic find, the $13^{\text {th }}$ century? (PL; after Głosek 1996, 90, tab. XV: F). All iron.

instead of circles, on one side of its blade. This axe head was dated to the second half of the 13th century at latest (Měchurová 2013, 626, fig. 4). On the matter of the discussed decoration we can mention the hoe head from the northern basement of the small fortress within the medieval village of Konůvky (Fig. 4: 2) as well. This fortress ceased to exist in the first half of the $15^{\text {th }}$ century. The inner cheek of the given hoe head is decorated with two branchlets in serial order that contain punched lines and dots (Měchurová 2013, 627, fig. 5). Within the Polish collections M. Głosek (1996, 94, tab. XVI: C) also found one axe head 
from an unknown site (Fig. 5: 2), which has got two branchlets in the place of its neck and cheek. These branchlets consist of punched lines and dots/circles. He suggested to date this exemplar to the $13^{\text {th }}-16^{\text {th }}$ centuries.

Rosettes (Čepička/Dolínek 1991, 18, fig. 14; Głosek 1996, 84, 93, tab. XIV: E; XXXI: A), crosses (Emandi 1981a, 169, fig. 4: 1; 1981b, 56, fig. 21: 1; Gtosek 1996, 93, XXXI: A), and other formations (Gtosek 1996, 91, 94, tab. XXIII: A, D), which comprise punched lines, dots/circles or little rosettes/flowers, can be observed on other five axe heads from Romania, Poland, and the Czech Republic. They, of course, are not a part of the decoration of the axe head from Balta Neagră, but are just similar to its decoration. Despite they were dated by researchers within the time span of the $13^{\text {th }}-16^{\text {th }}$ centuries, we do not know much about their find context.

In late medieval and early modern Western and Central Europe several exemplars of the weapon called doloir/wagoner's axe (in English), doloire (in French) or topór taborowy/berdysz (in Polish) were embellished with punched ornaments that we have dealt above with. Various branchlets compositions, quite simple or complex, which consist of dots, lines, and sickles, used to appear, often along with makers' marks, on the given weapon kind (Měchurová 2013, 622, footnote 3). This weapon and tool in one is typical for its blade that is quite large heavy triangle, whose back is blunt and cutting edge is sharp (Waldman 2005, 199-201, fig. 160). We can identify the aforementioned punched decoration within L. Marek's type 2 and 3 of the European doloir that might be dated to the $16^{\text {th }}-17^{\text {th }}$ centuries (Marek 2008, 129, 130, 169, 348, fig. 175: e-f). All things considered, doloirs punched with makers' marks and branchlets, which consist of lines, dots, and even quite short bent curves (e.g. Fig. 5: 3), can be dated on the basis of the recent studies to the $15^{\text {th }}-16^{\text {th }}$ centuries or possibly even to the $17^{\text {th }}$ century (Marek 2008, 128-130, fig. 175: e-f; Zdaniewicz 2016, 269, fig. 2-5).

Concerning the decoration of relatively short bent and cogged curves on the axe head from Balta Neagră it should be noted the following. Various cogged patterns that consist of punched/engraved lines of triangles projecting to one side (in the form of pointillé decoration) might be observed on the axe head from Fântâna Mare (Fig. 6: 1; inv. no. 178595 in the MNIR). This axe head is dated to the $15^{\text {th }}$ century according to its find context (Bătrîna/Monoranu/Bătrîna 1984, 165, 172, 174, fig. 5: 1). Other relevant features were punched on the double-edged weapon or prop from the Slovak National Museum in Martin (Fig. 7; inv. no. KH5955). There are at least five cogged curves (with semicircles projecting to their one side) connected to flowers/rosettes on its blade (Pivková 2016, 60-62, fig. 41; 42). Even though this weapon/prop was on the basis of its blade ${ }^{6}$ dated between the end of the $14^{\text {th }}$ century and the beginning of the $16^{\text {th }}$ century (Pivková 2016, 62), the recent unpublished research indicates that the object as a whole (along with its loop guard) points to the later stages of the Modern Period, i.e. the $18^{\text {th }}-19^{\text {th }}$ centuries (?; Žákovský 2014a, 176, 177).

We reckon that the examined axe head from Balta Neagră most likely belongs to the end of the High Middle Ages, Late Middle Ages or Early Modern Period and we estimate its production sometime between the $13^{\text {th }}$ and $17^{\text {th }}$ century. In addition, its shape indicates that could be employed in wood processing. This shape of axe head, the broad axe, might be used especially for the hacking of trunks and beams (Janotka/Linhart 1984, 100, 101; Štajnochr 1978, 159-157, tab. X: 1, 2; Žákovský/Schenk 2017, 32, 33).

\section{Cogged lines}

During the archaeological excavation of the private feudal chapel in Fântâna Mare in 1982, where 12 tombs were discovered as well, an axe head (Fig. 6: 1) was unearthed. It was most likely not related to the given tombs and we can recognise it as a (stray) find from the first phase of this edifice that was founded in the $15^{\text {th }}$ century (Bătrîna/Monoranu/Bătrîna 1984, 165, 172, 174, fig. 5: 1). Following the Museum register of the MNIR, it was received by this museum in 1986 (inv. no. 178595), probably after its restoration.

About shapes of the examined head we can claim the following: the well preserved iron axe head of a beard axe is angular in shape. The edge of a blade contains a visually recognisable dark strip of steel, which is $1.25-1.8 \mathrm{~cm}$ wide. The butt of the aforementioned head is flat and rectangular at its end. The given axe head is symmetric in cross-section from above or below and from these angles it is triangular in shape. The cutting edge of the blade was sharpened symmetrically as well. The eye has

6 The shape of the object's blade (but not its lenticular cross-section) might correspond with P. Žákovský type B1b (Žákovský 2014a, 226, tab. 26, fig. 175) of dussack blades from Moravia and Silesia within the Czech Republic as well as with dussacks of L. Marek's type I (Marek 2008, 46-49). 


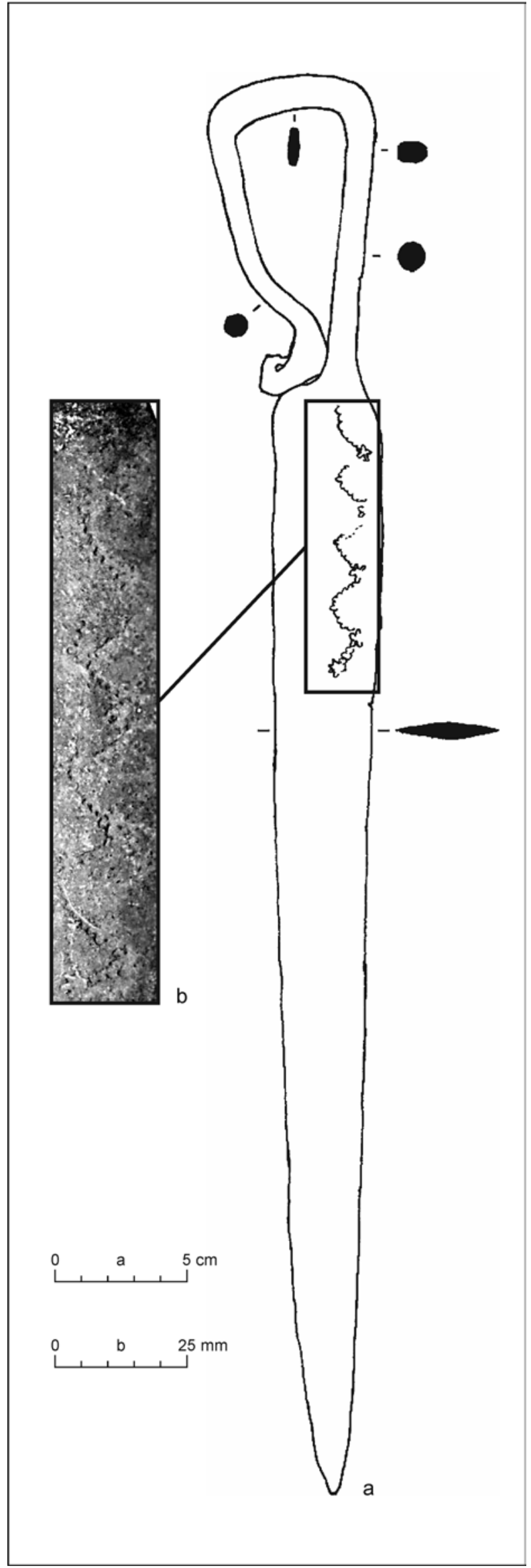

got its upper part slightly wider than its lower part and is distinct in profile or forms a relatively short socket. The axe head was decorated by punched lines with small triangles (triangles were punched in the sense of pointille decoration) that project to their one side and thus make up cogged lines. The punched decoration forms zig zag, cross (also in the shape of St. Andrew's cross), branchlet, and radial patterns.

As we stated before, the axe head can be dated to the $15^{\text {th }}$ century. Also, it is possible to find its analogies from Central Europe that are almost solely connected with its form in profile. However, they lack its symmetric triangular shape from above and below. From these angles, their eyes and butts are wider than thinner sections of their necks, cheeks and blades, although they are symmetrically arranged. M. Głosek (1996, 39, 40, 80, 99, tab. IV; XV-XVI) identified specimens of sub-type VIIIa (e.g. Fig. 6: 2) among late medieval axe heads from the territory of present-day Poland. Their shapes are similar to the examined axe head and he dated them from the second half of the $13^{\text {th }}$ century to the $16^{\text {th }}$ century. Furthermore, the recently found axe head from Michałowice in Poland belongs to this sub-type and should be dated alike (Szmoniezwski/Tunia 2016, 686, fig. 2).

In spite of the fact that on Viking Age and high medieval axe heads from Northern and Eastern Europe we can find incised/punched lines a triang$\mathrm{les}^{78}$, they do not match the decoration of the axe head from Fântâna Mare (Paulsen 1939, 55-79, fig. 23-35). However, concerning the decoration of the referred axe head two weapons from the later time periods should be presented and we should also repeat what we have already stated before. The first one is the stray find of the axe head from Valea Mărului (Fig. 4: 1; Galați County) that comes from Romanian Moldova, as the axe head from Fântâna Mare. This stray find was broadly dated to the time after the middle of the second millennium $\mathrm{AD}$ by C. Croitoru (2016, 337, fig. 4). The head is embellished by complex punched decoration. The relevant part, which concerns the axe head from Fântâna Mare, comprises a branchlet that was applied between the upper part of the neck and eye in the form of pointillé decora-

7 And even various stamps, dots, circles, rectangles, and their combinations.

Fig. 7. Double-edged weapon or prop from an unknown site that is deposited in the Slovak National Museum in Martin (not clear find context, inv. no. KH5955, the 18th-19th centuries (?); photograph and figure after Pivková 2016, 62, fig. 41; 42). All iron. Scale: a - a; b - b. 
tion. ${ }^{8}$ This axe head is asymmetric in cross-section from above or below. In the end, the aforementioned blade of the double-edged weapon or prop from the Slovak National Museum in Martin (Fig. 7; Slovakia; inv. no. KH5955) was decorated by at least five cogged curves, which have got semicircles projecting to their one side and are linked to flowers/rosettes. As I have stated before, the referred weapon might not belong to the Early Modern Period, but it would rather be dated to the later time period.

The shape of the examined axe head was most likely a part of an axe for general use (Janotka/Linhart 1984, $100,101)$ or an axe particularly used to notch and splinter wood and its further processing ${ }^{9}$ (Štajnochr 1978, 157-159, tab. VI-IX; Žákovský/Schenk 2017, 33).

\section{Quatrefoil}

The axe head from Suceava (Fig. 8: 1), which is deposited and registered in the MNIR under no. 72492, was transferred to this museum from the Bukovina Museum in Suceava in 1975, according to the information from the Museum register of the MNIR.

The iron axe head has got a pointed beard. The eye of the axe head is distinct in profile or forms a relatively short socket. The upper part of the eye is wider than its lower part. The butt of the discussed axe head is rectangular and flat at its end. The axe head from Suceava is symmetric from the upper and lower angle of vision and the cutting edge of the blade tapers symmetrically too. There is a decoration in the form of a quatrefoil, which was punched on one side of the axe head, directly in the place of its neck. It would have been a possible maker's mark as well.

The form of the referred axe in profile can be recognised at several exemplars from Central Europe and even from present-day Romania. In the area of Romanian Bukovina a similar symmetric axe head was found in Coșna-Floreni. I.-E. Emandi (1981b, 40, fig. 10: 1) dated this specimen to the $13^{\text {th }}-14^{\text {th }}$ centuries. Then similar exemplars can also be found in Eastern Germany during the $12^{\text {th }}-13^{\text {th }}$ centuries (Heindel 1992, 32, 33, fig. 14: a), in Poland between the $13^{\text {th }}$ century and the $16^{\text {th }}$ century (e.g. Fig. 8: 2; Gtosek 1990, 138, 502, fig. 22; 1996, 40-42, 80, tab. 4; 17-20) ${ }^{10}$, and in Slovakia probably during the 16th century (Klčo 1988, 76, fig. 16; Novotný 1965, 76, 78, tab. XII: 1, 2, 7).

8 On the base of the available figure and information (Croitoru 2016, 337, fig. 4) we cannot also exclude the presence of cogged lines there.

9 The axe called "hlavatka“ in the Czech and Slovak language.

10 These specimens are from the collections of present-day Poland that M. Głosek (1996, 40-42, 80, tab. 4; 17-20) integrated into his type IX of late medieval axe heads, whose shapes the referred exemplar owns.

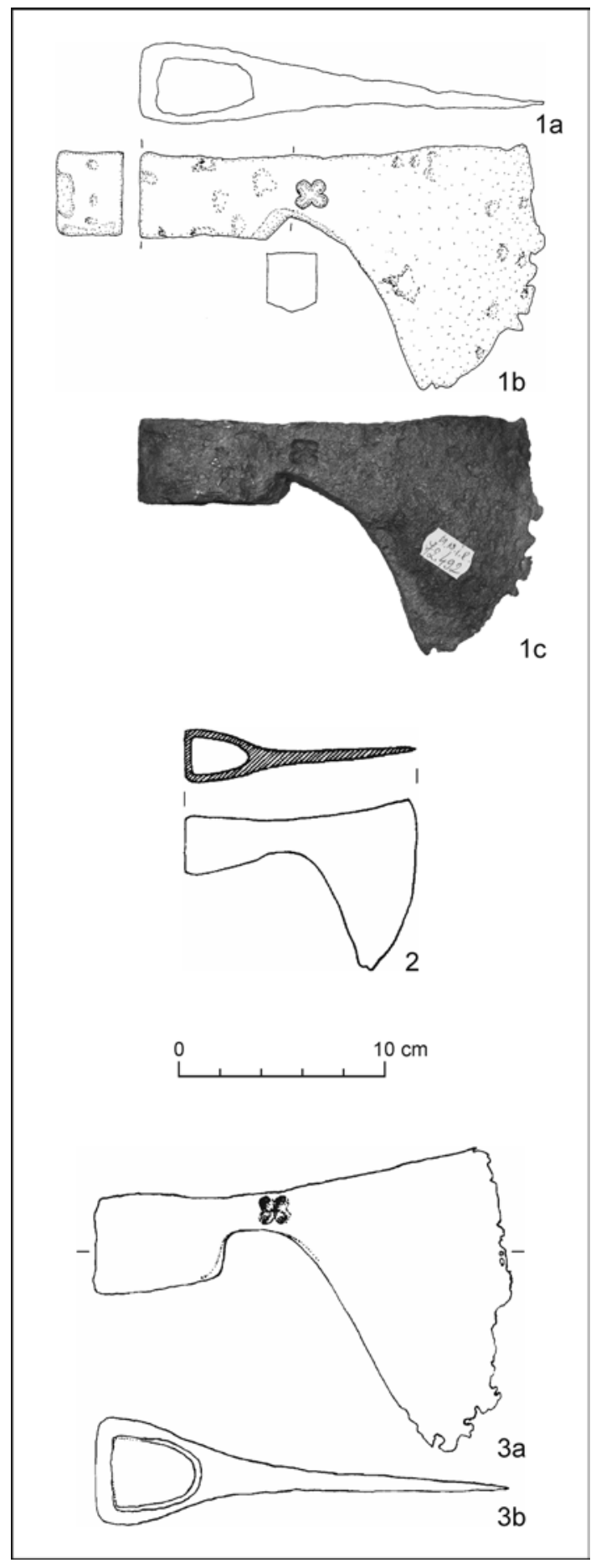

Fig. 8. Examined medieval and early modern axe head from Suceava (inv. no. 72492) deposited in the National Museum of Romanian History in Bucharest (RO) and analogies for its features. 1 - Suceava, not clear find context, the end of the $13^{\text {th }}$ century/ $15^{\text {th }}-16^{\text {th }}$ century (Suceava County, $\mathrm{RO}$, inv. no. 72492 in the MNIR; drawings and a photograph by M. Husár); 2 - Siedlątków, stray find from the area of the castle, about the year 1380 (PL; after Głosek 1990, 138, 502, fig. 22); 3 - Moravany nad Váhom-Hubina, aquatic find, the middle of the $16^{\text {th }}$ century (SK; after Klčo 1988, 76, fig. 16). All iron. 

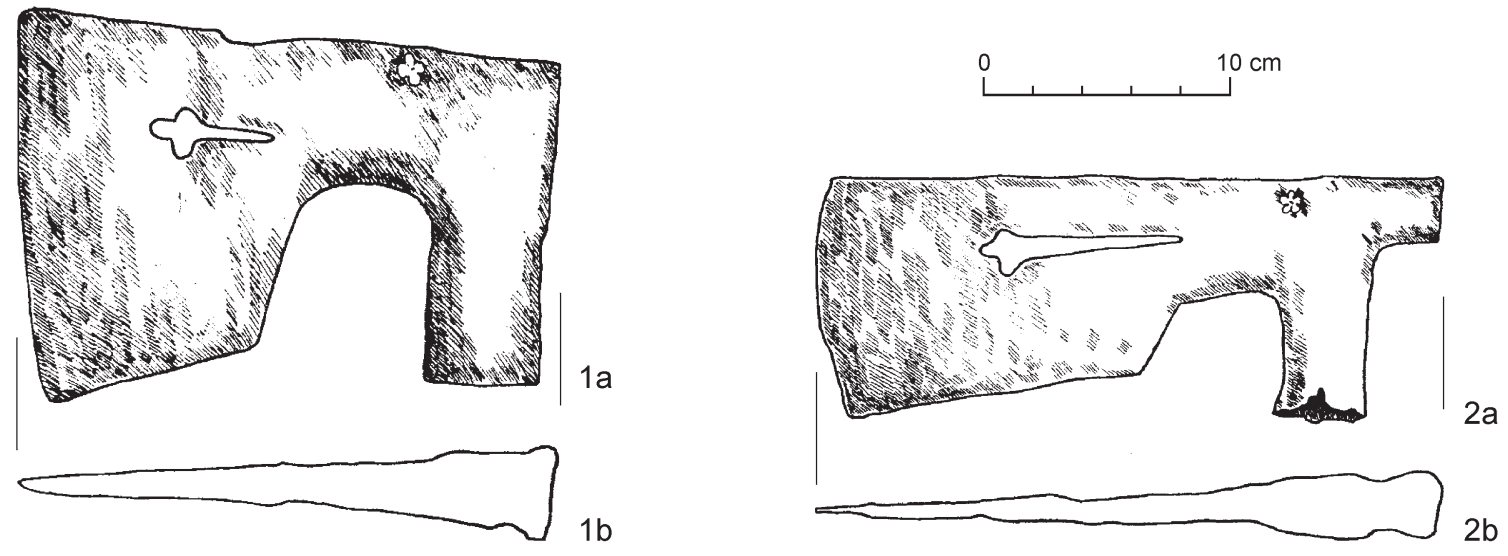

Fig. 9. Analogies for features of the examined medieval and early modern axe head from Suceava (inv. no. 72492) deposited in the National Museum of Romanian History in Bucharest (RO). 1 - Baia Mare, the $15^{\text {th }}-16^{\text {th }}$ centuries (Maramureș County, RO, after Emandi 1981b, fig. 22: 2); 2 - Baia Mare, the $15^{\text {th }}-16^{\text {th }}$ centuries (Maramureș County, RO, after Emandi 1981b, fig. 22: 5). All iron.

The almost same axe head (Fig. 8:3) in shape and with the same decoration (as the referred axe head) was found during the extraction of gravel near the River Váh, close to Moravany nad Váhom-Hubina in present-day Slovakia. M. Klčo $\left(1988,76\right.$, fig. 16) dated this axe head to the middle of the $16^{\text {th }}$ century. Also there are two axe heads from Baia Mare in Romanian Maramureș County that were punched on one side of their necks by quatrefoil (Fig. 9: 1; Emandi 1981b, fig. 22: 2) and cinquefoil (Fig. 9: 2; Emandi 1981b, fig. 22: 5) decorations or marks. Nonetheless, they are of different forms in profile from the exemplar from Suceava and they have openwork cheeks with a shamrock pattern. Both of them were dated to the $15^{\text {th }}-16^{\text {th }}$ centuries by I.-E. Emandi $(1981 b, 56)$ in 1981.

Various punched/stamped decorations or makers' marks, although not in a quatrefoil form, can be observed on late medieval axe heads of the above mentioned type IX defined by M. Głosek for Poland. Earliest ones should be dated within this type to the end of the $13^{\text {th }}$ century or to the $14^{\text {th }}$ century (Gtosek 1996, 41, 42). However, exemplars with only one maker's mark in the place of their necks might belong to the $14^{\text {th }}-16^{\text {th }}$ centuries (Gtosek 1996, 88, 90-92; nr. kat. 64; 91; 115; tab. XIX: E; XX: G; XXI: C). B. Novotny $(1956,346)$ dated late medieval axe heads from Bohemia, which were inlaid and labelled with makers' marks, between the end of the $14^{\text {th }}$ century and the beginning of the $16^{\text {th }}$ century.

Taking the stated facts into consideration, it seems to us that we might date the examined axe head from Suceava from the end of the $13^{\text {th }}$ century or the course of the $15^{\text {th }}$ century to the $16^{\text {th }}$ century. The referred axe head was a part of an axe that might have been intended just for general use (Janotka/Linhart 1984, 100, 101).

\section{Openwork cheek and blade and concave cuts}

In 1975 the axe (Fig. 10), which originated from an unknown place, was brought from the History Museum of Braşov to the MNIR, where it was labelled by inv. no. 37793. The Museum register of the MNIR formerly dated this object to the $15^{\text {th }}$ century.

The axe consists of an iron head and wooden handle. The blade of the head is convexly curved. The iron axe head was made asymmetric in cross-section from above or below and the cutting edge of its blade was sharpened asymmetrically as well. The blade and cheek of the head were decorated by cutting and piercing. There are 9 circular holes $(0.4 \times 0.4 \mathrm{~cm}$ in diameter $)$ in the blade and cheek arranged in the circle and 6 concave cuts, which reach the cheek and neck of the head. On one side of the neck it can be noticed a maker's mark that was punched. It is composed of an irregular pentagonal formation, from which a lime tree leaf and branch probably rise up (Fig. 10: c). The neck is quite long. The eye of the head is prolonged downwards (5.8 cm under the neck) in the form of a socket, which is semi-oval in cross-section. The quite shortly protruding butt of the axe head is flat and slightly trapezoid at its end. The blade is evenly widened out. Under the eye/socket of the axe head, i.e. on the surface of the handle, 


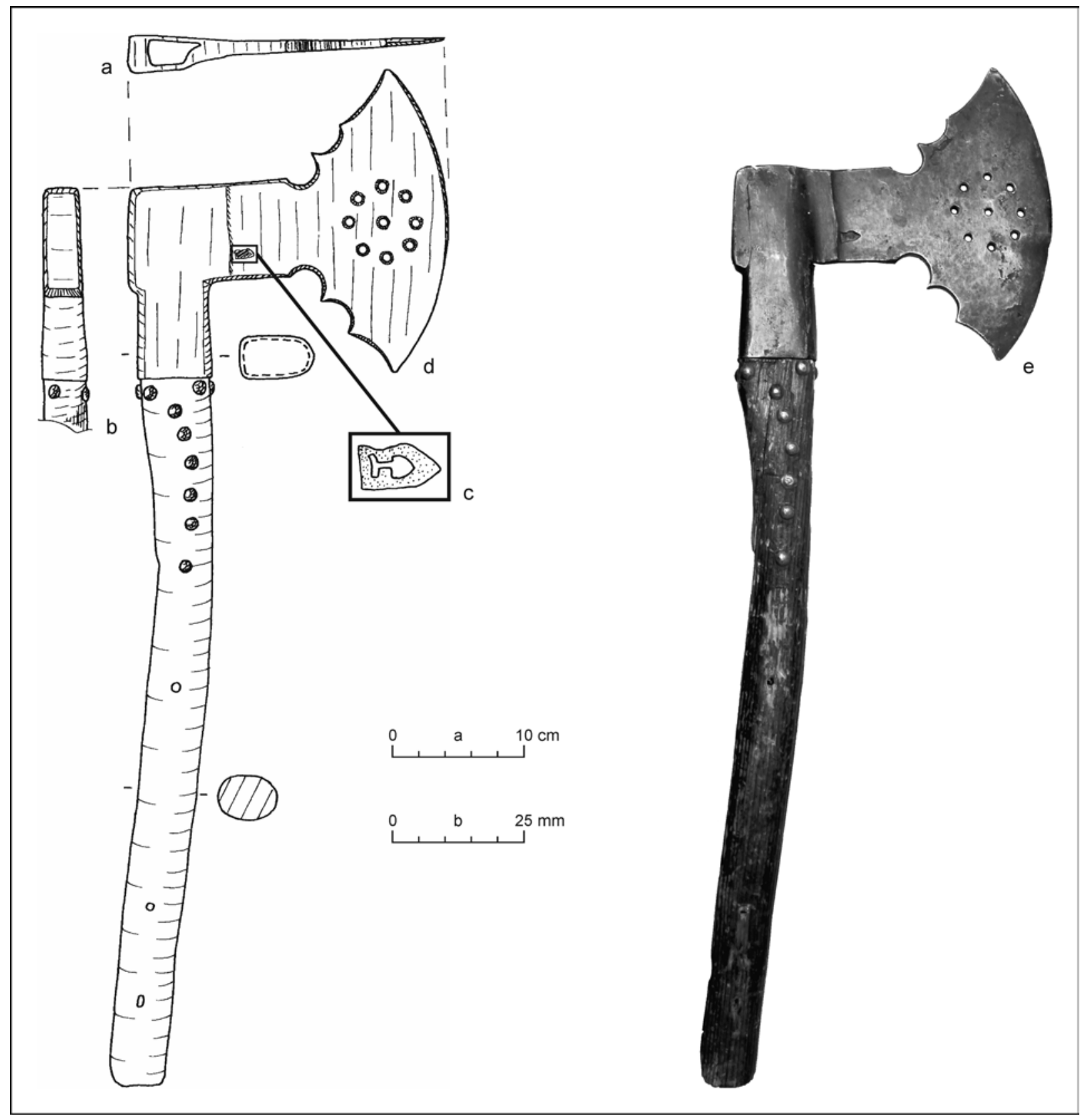

Fig. 10. Examined medieval and early modern axe (unknown site, inv. no. 37793 , the $15^{\text {th }} / 16^{\text {th }}-17^{\text {th }}$ centuries) from the National Museum of Romanian History in Bucharest (RO). a, b, d - drawings by G. Ducman; c, e - drawing and photograph by M. Husár. a, c - iron; b, d-e - iron, non-ferrous yellow metal, wood. Scale: a - a-b, d-e; b - c.

10 (nail) heads (diameter: $0.9 \times 0.9 \mathrm{~cm}$, height: $0.3 \mathrm{~cm}$ ) made of yellow non-ferrous metal are seen. At the back of the handle, there is one visible head (diameter: $0.35 \times 0.4 \mathrm{~cm}$ ) of a probable recent nail. Recently, the handle of the axe, which is made of an unknown wood, was most likely drilled three times through. The handle is semi-oval in cross-section, where it comes into contact with the mouth of the eye/socket, and oval in cross-section at its opposite end.

There is no direct analogy for the given axe (head), but we may date it according to some features, which can be observed on other contemporary axes, bardiches, guisarmes, pollaxes, halberds, and boar spears. The above mentioned features are: a convexly curved blade, pierced head, concave cuts applied on the neck and cheek of a head, a quite long neck, flat butt, and maker's mark.

The closest parallels to the referred axe head might be three almost identical bardiche heads from Polish, Romanian and Ukrainian museum collections. Namely they are from the collections of the National 


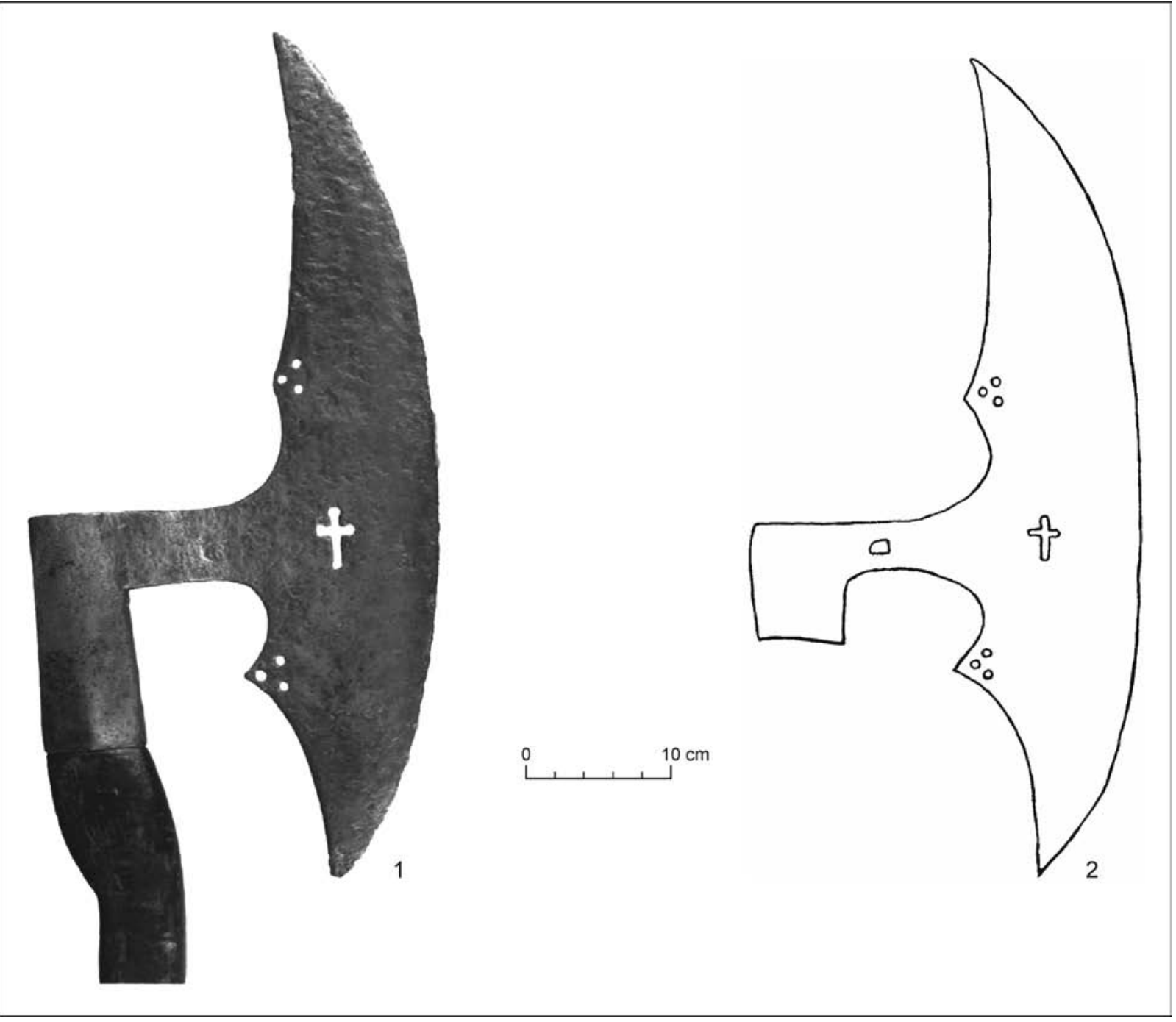

Fig. 11. Analogies for features of the examined medieval and early modern axe (inv. no. 37793) from the National Museum of Romanian History in Bucharest (RO). 1 - Wawel royal castle in Cracow (PL?), inv. no. dep. 2573, the 17 $7^{\text {th }}$ century (after Czyżewski 2013, 235-237, 409, fig. on page 235-237, 409); 2 - Lviv Historical Museum (Львiв?), inv. no. 3-3532, the $16^{\text {th }}-17^{\text {th }}$ centuries (after Terskyj 2005, 21, 23, 24, fig. 4: 18). 1 - iron, wood; 2 - iron.

Military Museum in Bucharest - Pavilion B, Exhibition of armament (unknown site, from Germany?) ${ }^{11}$, collections of the Wawel Royal Castle in Cracow - inv. no. dep. 257 (Fig. 11: 1; Czyżewwski 2013, 235-237, 409, figures on page 235-237, 409; from Poland?), and collections of the Lviv Historical Museum - inv. no. 3-3532 (Fig. 11: 2; Terskyj 2005, 21, 23, 24, fig. 4: 18; from 1ьвiв?). All of them are fitted with convexly curved blades, quite long necks, four concave cuts on their cheeks pierced by 6 (grouped into threes) circular holes, which are between the above mentioned concave cuts, and by a cross-shaped perforation between their cheeks and blades. They have also got various marks of their makers. The find contexts of these bardiches are not known and they were dated variously - to the second half of the $15^{\text {th }}$ century (accompanying text of the Exhibition of armament in the National Military Museum in Bucharest), the $17^{\text {th }}$ century (Czyżewski 2013, 235-237, 409), and to the $16^{\text {th }}-17^{\text {th }}$ centuries (Terskyj 2005, 21, 23, 24). Bardiche heads from Bucharest and Cracow are connected to quite long shafts. The Exemplar from Cracow measures $180.5 \mathrm{~cm}$ altogether, although the referred axe from the MNIR just $61.9 \mathrm{~cm}$.

Concerning the 9 circular holes in the blade and cheek of the examined axe head, which are arranged in the circle, we should mention four weapon parallels from the collections of European museums. Into

11 This weapon is unpublished and one author of this article, M. Husár, just saw it in the particular exhibition of the National Military Museum in Bucharest. 


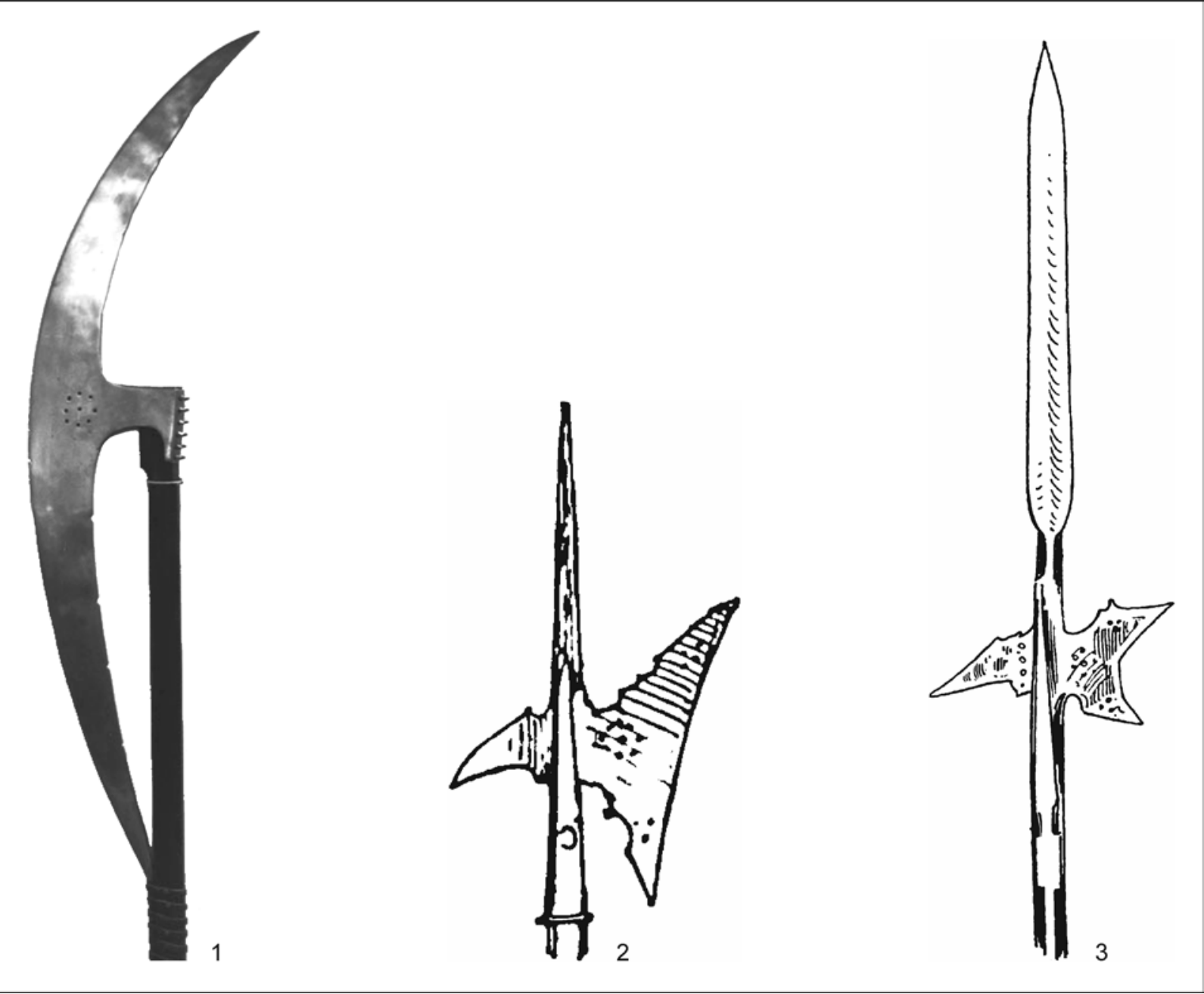

Fig. 12. Analogies for features of the examined medieval and early modern axe (inv. no. 37793) from the National Museum of Romanian History in Bucharest (RO). 1 - Danish War Museum in Copenhagen (RF?), inv. no. C50, the year 1530 (after Waldman 2005, 166, 167, fig. 135); 2 - collection of Verfaffer (CH?), the middle of the $16^{\text {th }}$ century (after Demmin 1893, 825, 826, fig. 13); 3 - collection of Van Zuylen (NL?), the beginning of the $1^{\text {th }}$ century (after Boeheim 1890, 337, fig. 392: c). 1 - iron, brass, wood; 2, 3 - probably iron and wood. Not to scale.

this group we can place the Russian quisarme with it's over a meter long blade and total span of $2.17 \mathrm{~m}$, which is deposited in the Danish War Museum (former Royal Danish Arsenal Museum - Tøjhusmuseet in Danish) in Copenhagen, under inv. no. C50. This weapon dated to the year 1530 has got 9 circular holes that are pierced through the cheek of its head (Fig. 12: 1; Waldman 2005, 166, 167, fig. 135). Then there is one Swiss halberd from the Collection of Verfaffer (Fig. 12: 2; Demmin 1893, 825, 826, fig. 13), whose blade and cheek are pierced by 15 circular holes grouped into two threes and one group of 9 holes. According to A. Demmin $(1893,826)$ the halberd belongs to the middle of the 16th century. 9 circular holes in the blade and cheek accompanied by other circular holes ${ }^{12}$ can be observed at two subsequent halberds too: the Dutch halberd (Fig. 12: 3; Boeheim 1890, 337, fig. 392: c) from the collection of Van Zuylen and the German halberd (Fig. 13: 1; Boeheim 1890, 341, fig. 394) from the Hohenzollern Palace Armoury (former Princely Hohenzollern Museum) in Sigmaringen. Wendelin Boeheim dated them to the beginning of the $17^{\text {th }}$ century (Boeheim 1890, 337) and the end of the $16^{\text {th }}$ century (Boeheim 1890, 341).

The rest of the parallels (axes, bardiches, halberds, or pollaxes) to the discussed axe regard concave cuts (from two to eight) on their heads (or directly on cheeks) and in some cases also various perforation patterns of their heads. They come from various collections from Europe and North America, but they

12 In the first case by the group of two threes and in the following case by the group of one three. 
are connected with the European continent and particularly with Austria, Denmark, Germany, Hungary, Moravia, Russia, and Swiss (e.g. Fig. 13: 2; Boeheim 1890, 338, 341, 372, fig. 392: e-f; 395; 440; 441; Demmin 1893, 818, 819, 825, 826, fig. 5; 8; 11; Kalmár 1971, 33, 39, fig; Oakeshott 2000, 50, fig. 9: B-C; Stone 1961, 111, fig. 142: 2-4; Waldman 2005, 157, fig. 126). Their time of usage can be set between the $15^{\text {th }}$ and $17^{\text {th }}$ century that is based on the dating of particular exemplars made by assessments of several researchers. Two iconographical representations confirm the dating of weapons with concave cuts since the $15^{\text {th }}$ century. The illustrator of the Radziwiłl Chronicle $\left(15^{\text {th }}\right.$ century; St. Petersburg, Russia) depicted one axe with one concave cut on the cheek of its head (Fig. 14: 1; Radziwitt Chronicle) $)^{13}$ and two axes with two above mentioned concave cuts (Fig. 14: 1, 2; Radziwitt Chronicle $^{14}$. Then there is one bardiche with quite long neck and four concave cuts on the cheek its head (Radziwitt Chronicle; Terskyj 2005, 21, pис. 3). ${ }^{15}$ Four or even six concave cuts on the cheek belong to the pollaxe/Mordaxt on the anonymous German woodcut dated circa between the year 1460 and 1470 (Waldman 2005, 158, fig. 127).

According to L. Belcredi (1989, 451, 453, tab. 5: 294), who created the terminology, classification, and code of medieval metal items, a flat butt appeared on axe heads during the $15^{\text {th }}$ century. This feature is present on the examined axe as well.

Probably the same maker's mark (a lime tree leaf and branch), as occurs on the referred axe, we can recognise on two military boar spears, which are most likely from the early $16^{\text {th }}$ century. They are placed in the Tower of London (the presentday United Kingdom; Ffoulkes 1916, 221, 488, makers' marks nos. 54, 56, Appendix B: 170, 171).

We suppose that the axe registered in the MNIR under inv. no. 37793 can most likely be dated to the $15^{\text {th }} / 16^{\text {th }}-17^{\text {th }}$ centuries. The features of this axe are mostly connected with aforementioned arms and we may therefore assume this object to be a weapon. As far as we know there is not its analogy among contemporary medieval and modern axes used as tools.

\section{CONCLUSION}

The discussed objects - the decorated axe and three axe heads - from the MNIR belong to the transitional period between the Middle Ages and Modern Period. Each of them was embellished in a different way. Whereas the axe heads from Balta Neagră, Fântâna Mare, and Suceava are decorated by various punched decorations, the axe indexed under inv. no. 37793 was adorned by 6 concave cuts related to its openwork cheek and blade. A maker's mark, which most likely contains a lime tree leaf and branch, is its only punched decoration and there are 10 assumed nails in its handle as well. On the surface of the first three axe heads various combinations of lines, curves, circles, cogged lines, and cogged curves were applied. They created the letter X, cross, branchlet (cogged ones and those made of

\footnotetext{
13 http://radzivilovskaya-letopis.ru/index.php?id=208\#sel [3. 7. 2019]

$14 \mathrm{http} / / /$ radzivilovskaya-letopis.ru/index.php?id=208\#sel; http://radzivilovskaya-letopis.ru/index.php?id=338\#sel [3. 7. 2019]

15 http://radzivilovskaya-letopis.ru/index.php?id=221\#sel [3. 7. 2019]
} 

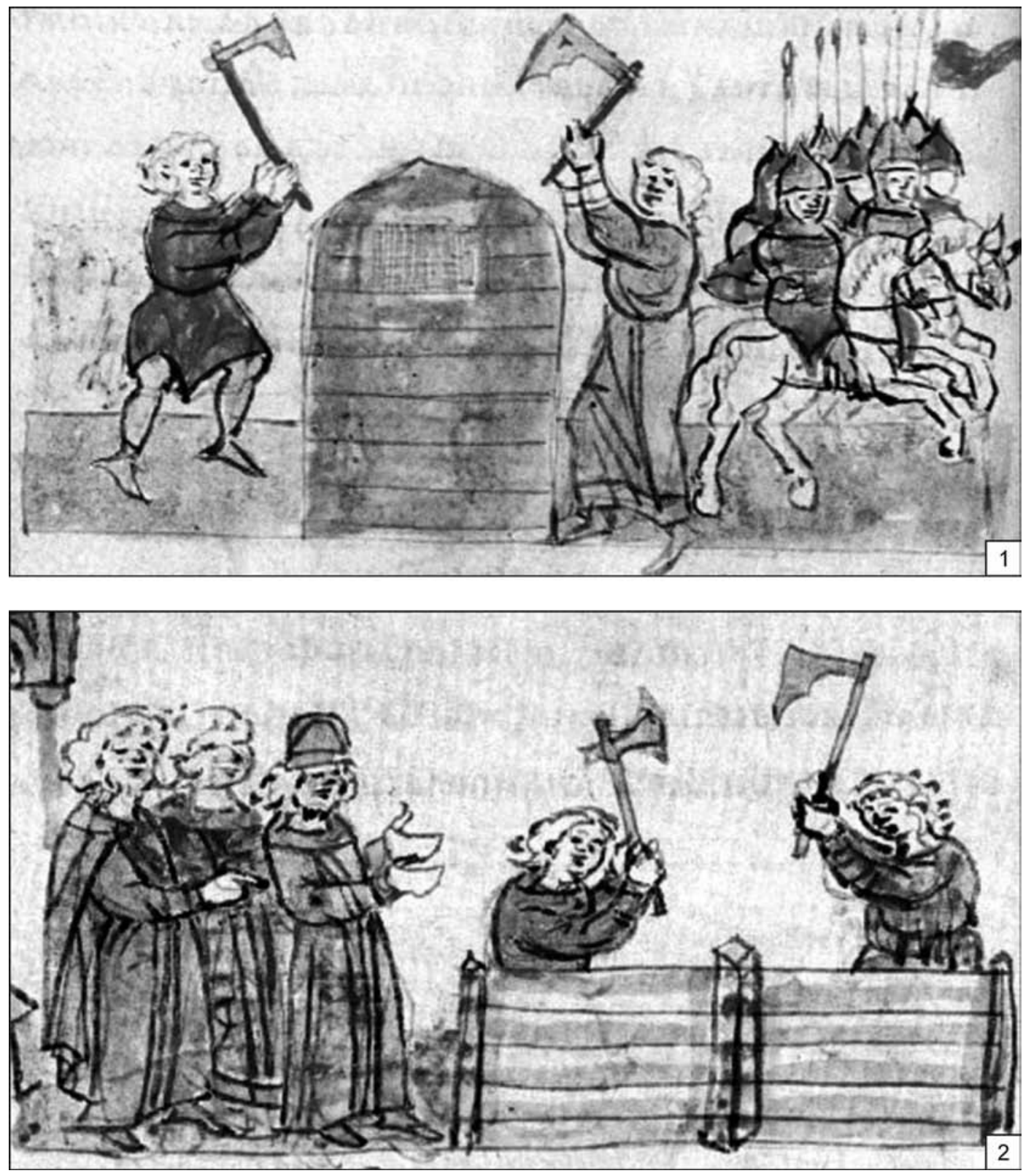

Fig. 14. Analogies for features of the examined medieval and early modern axe (inv. no. 37793) from the National Museum of Romanian History in Bucharest (RO). Illustrations of the Radziwiłł Chronicle; $15^{\text {th }}$ century (after Radziwitt Chronicle).

three radially converging lines with circles at their ends), short bent cogged curve, rhomboid, sun-like, radial, and zig-zag patters.

The exemplar from Balta Neagră and Suceava can probably be perceived as oldest objects from the examined assemblage. They might already have been produced in the $13^{\text {th }}$ century (Balta Neagră) and at the end of this century or in the $15^{\text {th }}$ century (Suceava). The making of the specimen from Suceava could have taken place yet in the $16^{\text {th }}$ century at latest, but the axe head from Balta Neagră might have been made even yet in the $17^{\text {th }}$ century or during the course of the Early Modern Period. The find context (the first phase of the private feudal chapel) of the specimen from Fântâna Mare clearly allows us to date it to the $15^{\text {th }}$ century. The possible latest axe head from the examined assemblage would have been the exemplar with inv. no. 37793, which is dated to the $15^{\text {th }} / 16^{\text {th }}-17^{\text {th }}$ centuries.

Parallels to all the examined exemplars were not identified just in Romania, but also in Europe. Even though the specimen from Balta Neagră has got some common features (in regard to their form) with 
the early (and high) medieval Lunow type of axe heads, its decoration evidently speaks for the high/late medieval and early modern analogies from Western and Central Europe. We can mention Central European parallels from the Late Middle Ages and the High and Late Middle Ages/Early Modern Period for axe heads from Fântâna Mare and Suceava. The specimen with inv. no. 37793 could be derived from the late medieval and early modern Western, Central, Northern or Eastern Europe.

In the matter of the utilisation of the examined objects we should designate some of them as a part of a tool and some as a part of a weapon. The axe head from Balta Neagră and maybe the axe head from Fântâna Mare as well were most likely used as parts of tools for wood processing. The specimen from Suceava and possibly also the specimen from Fântâna Mare would have been used as axes for general use. Lastly, the axe with inv. no. 37793 was likely produced for combat use.

\section{Acknowledgements}

This work was supported by the Cultural and Educational Grant Agency of the Ministry of Education, Science, Research and Sport of the Slovak Republic under the contract No. 004UKF-4/2018. The authors thank Czech archaeologist P. Žákovský and Polish archaeologists $P$. Kotowicz and R. Liwoch from whom they have obtained a lot of useful advice and the information on medieval and early modern age axes from Central Europe. Last but not least, the authors appreciate an open attitude of the director of the MNIR, E. Oberländer-Târnoveanu, to the processing of the studied weapons.

\section{LITERATURE}

Andronic/Popescu 1980

Bătrîna/Monoranu/Bătrîna 1984

Belcredi 1989

Boeheim 1890

Croitoru 2016

Czyżerwski 2013

Čepička/Dolínek 1991

Dejan/Ilie 2017

Demmin 1893

Emandi 1981a

Emandi $1981 b$

Ffoulkes 1916

Głosek 1990

Głosek 1996

Heindel 1992

Ilie/Dejan 2018

Janotka/Linhart 1984

Jotov 2004

Kalmár 1971

Klčo 1988
A. Andronic/R. Popescu: Principalele rezultate ale cercetărilor arheologice de la Vaslui-Curțile Domnești din anul 1978. Acta Moldaviae Meridionalis - Anuarul Muzeului Județean Vaslui 1, 1980, 119-128.

L. Bătrîna/O. Monoranu/A. Bătrîna: Cercetările arheologice de la Fîntîna Mare, com. Vadul Moldovei, jud. Suceava. Cercetări arheologice 7, 1984, 165-174.

L. Belcredi: Terminologie, třídení a kód středověkých kovových předmětů. Archaeologia historica 14, 1989, 437-472.

W. Boeheim: Handbuch der Waffenkunde. Leipzig 1890.

C. Croitoru: Topoare medievale identificate în județul Galați. Tyragetia. Arheologie Istorie Antică. Serie Nouă 10 [25]/1, 2016, 333-344.

K. J. Czyżewski: Broń drzewcowa w zbiorach Zamku Królewskiego na Wawelu. Cracow 2013.

L. Čepička/V. Dolínek (eds.): Výběrový katalog Vojenského historického muzea. Praha 1991.

M. Dejan/O. Ilie (eds.): Ştefan cel Mare: din istorie în veșnicie. Suceava 2017.

A. Demmin: Die Kriegswaffen in ihren geschichtlichen Entwickelungen von ältesten Zeiten bis auf die Gegenwart. Leipzig 1893.

I.-E. Emandi: Topoare din fier - tip bardă cu tub de înmănuşare din Europa Centrală, în perioada Evului mediu dezvoltat. Memoria Antiquitatis 6-8, 1981, 163-184, fig. 1-10.

I.-E. Emandi: Cercetări privind uneltele de tăiat de pe teritoriul României, în perioada secolelor IX-XVII. Studii și comunicări de istorie a civilizației populare din România 2, 1981, 19-65.

Ch. J. Ffoulkes: Inventory and survey of the armouries of the Tower of London II. Offensive arms. London 1946.

M. Głosek: Broń drzewcowa i obuchova. In: A. Nadolski (ed.): Uzbrojenie w Polsce średniowiecznej. 1350-1450. Łódź 1990, 131-142.

M. Głosek: Późnośredniowieczna broń obuchowa w zbiorach polskich. Warszawa - Łódź 1996.

I. Heindel: Äxte des 8. bis 14. Jahrhunderts im westslawischen Siedlungsgebiet zwischen Elbe/Saale und Oder/Neisse. Zeitschrift für Archäologie 26, 1992, 17-56.

O. Ilie/M. Dejan (eds.): Ştefan cel Mare. Din istorie în veșnicie. Bucureşti 2018.

M. Janotka/K. Linhart: Zapomenutá řemesla. Vyprávění o lidech a věcech. Praha 1984.

V. Jotov: Văorăženieto i snariaženieto ot bălgarskoto srednovekovie (VII-XI vek). Varna 2004.

J. Kalmár: Régi Magyar fegyverek. Budapest 1971.

M. Klčo: Stredoveká železná sekera z Moravian nad Váhom-Hubiny. AVANS 1987, 1988, 76, fig. 16. 
Kotowicz 2011

Kotowicz 2013

Kotowicz 2014

Kucypera/Pranke/Wadyl 2010

Kucypera/Wadyl 2011

Marek 2008

Matei/Chițescu 2002

Měchurová 2013

Michalak/Kotowicz 2014

Nadolski 1954

Novotný 1956

Novotný 1965

Oakeshott 2000

Paulsen 1939

Pedersen 2002

Pedersen 2014a

Pedersen $2014 b$

Pivková 2016

Radziwitt Chronicle

Stone 1961

Szmoniewski/Tunia 2016

Štajnochr 1978

Štajnochr 1979

Terskyj 2005

Waldman 2005

Zdaniewicz 2016

Žákovský $2014 a$
P. N. Kotowicz: Early Medieval Ornamented Axes from the Territory of Poland. Studia Universitatis Cibiniensis 2011/VIII. Series Historica, Supplementum No. 1, 105-132.

P. N. Kotowicz: The Sign of the Cross on the Early Medieval Axes - a Symbol of Power, Magic or Religion? In: L. Marek (ed.): Weapons Brings Peace? Warfare in Medieval and Early Modern Europe. Wrocław 2013, 41-55.

P. N. Kotowicz: Topory wczesnośredniowieczne z ziem polskich. Katalog źródeł. Rzeszów 2014.

P. Kucypera/P. Pranke/S. Wadyl: Wczesnośredniowieczne miniaturowe toporki metalowe z Europy Środkowo-Wschodniej i Północnej. Korpus zabytków. In: P. Kucypera/S. Wadyl (eds.): Życie codzienne przez pryzmat rzeczy. Toruń 2010, 103-176. P. Kucypera/S. Wadyl: Early medieval miniature axes of Makarov's type 2 in the Baltic Sea Region. Archaeologia Lituana 12, 2011, 122-130.

L. Marek: Broń biała na Ślasku XIV - XVI wiek. Wratislavia Antiqua 10. Wrocław 2008. M. D. Matei/L. N. Chițescu: Cetatea de pământ de la Bârlad - monografie arheologică. Târgovişte 2002.

Z. Měchurová: Vybíjené ornamenty na středověkých sekerách. Archaeologia historica 38, 2013, 619-630.

A. Michalak/P. N. Kotowicz: Wczesnośredniowieczne cmentarzysko z okolic Bukowca $\mathrm{w}$ powiecie międzyrzeckim, czyli o pewnym odkryciu $\mathrm{w}$ archiwum w Wünsdorfie. Wielkopolskie Sprawozdania Archeologiczne 15, 2014, 107-124.

A. Nadolski: Studia nad uzbrojeniem polskim w X, XI a XII wieku. Acta archaeologica Universitatis Lodziensis 3. Łódź 1954.

B. Novotný: Tausované sekerky z Čech. Památky archeologické 47, 1956, 335-347.

B. Novotný: Nález železných predmetov v Nitre. Sborník Filozofickej fakulty Univerzity Komenského, Musaica 16 (5), 1965, 69-79.

E. Oakeshott: European Arms and Armour from Renaissance to the Industrial Revolution. Woodbridge 2000.

P. Paulsen: Axt und Kreuz bei den Nordgermanen. Berlin 1939.

A. Pedersen: Scandinavian Weaponry in the Tenth Century: The Example of Denmark. In: D. Nicolle (ed.): A Companion to Medieval Arms and Armour. Woodbridge 2002, 25-36.

A. Pedersen: Dead Warriors in Living Memory. A Study of Weapon end Equestrian Burials in Viking-Age Denmark, AD 800-1000. Publications from the National Museum, Studies in Archaeology \& History 20:1 1. Jelling Series. Copenhagen 2014.

A. Pedersen: Dead Warriors in Living Memory. A Study of Weapon end Equestrian Burials in Viking-Age Denmark, AD 800-1000. Publications from the National Museum, Studies in Archaeology \& History Vol. 20:1 2. Catalogue. Jelling Series. Copenhagen 2014.

A. Pivková: Meče a tesáky zo Slovenského národného múzea v Martine. Bachelor Thesis. Filozofická fakulta Masarykovy university, Ústav archeologie a muzeologie. Brno 2016. Unpublished.

The Radziwitt Chronicle. Library of the Russian Academy of Sciences in St. Peterburg. http://radzivilovskaya-letopis.ru [3. 7. 2019]

G. C. Stone: Glossary of the Construction, Decoration and Use of Arms and Armor in All Countries and in All Times. New York 1961.

B. Sz. Szmoniewski/K. Tunia: Średniowieczny topór z okolic Michałiwic, pow. Kaziemierza Wielka. In: B. Chudzińska/M. Wojenka/M. Wołoszyn (eds.): Od Bachórza do Światowida ze Zbrucza. Tworzenie się słowiańskiej Europy w ujęciu źródłoznawczym. Księga jubileuszowa Profesora Michała Parczewskiego. Kraków - Rzeszów 2016, 681-687.

V. Štajnochr: Tesařské sekery, nástroje a tesařské technologie. Muzejní a vlastivědná práce 16, 1978, 148-168.

V. Štajnochr: Tesařské sekery, nástroje a tesařské technologie (Dokončení studie z č. 3/78). Muzejní a vlastivědná práce 17, 1979, 14-39.

S. V. Terskyj: Z istoriji ukrajinskoji zbroji XIII-XVIII st.: sokyry-berdyši ta alebardy. In: L. Je. Deščynskyj (ed.): Visnyk Nacionalnogo universytetu "L'vivska politechnika" 528 - Deržava ta armia. Lviv 2005, 16-27.

J. Waldman: Hafted Weapons in Medieval and Renaissance Europe. The Evolution of European Staff Weapons between 1200 and 1650. Leiden - Boston 2005.

R. Zdaniewicz: Topór taborowy z Toszka - źródło do poznania wyposażenia piechoty w XV/XVI w. Rocznik Musuem v Gliwiciach 26, 2016, 265-269.

P. Žákovský: Tesáky a problematika jednosečných zbraní středověku a raného novověku. Dissertation Thesis. Filozofická fakulta Masarykovy university. Ústav archeologie a muzeologie. Brno 2014. Unpublished. 
Žákovský $2014 b$

Žákovský/Schenk 2017
P. Žákovský: Tesáky a problematika jednosečných zbraní středověku a raného novověku. Katalog jednosečných zbraní středověku a raného novověku z území Moravy a českého Slezska. Dissertation thesis. Filozofická fakulta Masarykovy university. Ústav archeologie a muzeologie. Brno 2014. Unpublished.

P. Žákovský/Z. Schenk: Středověké a raně novověké zbraně Přerovska. Zbraně a zbroj od kolapsu Velké Moravy do konce třicetileté války. Přerov - Brno 2017.

\title{
Zdobené stredoveké a včasnonovoveké sekery z Národného múzea rumunskej histórie v Bukurešti
}

\author{
Martin Husár - Silviu Ion Oța - Tudor Alexandru Martin
}

\author{
Súhrn
}

Príspevok je zameraný na tri zdobené hlavice sekier a jednu kompletnú sekeru z Národného múzea rumunskej histórie v Bukurešti (d’alej MNIR), ktoré môžeme datovat na prelom stredoveku a novoveku (tabela 1). Ide o obdobie medzi koncom vrcholného stredoveku a včasným novovekom. V MNIR sú predmety bádania vedené pod inventárnymi číslami 37793, 72492, 178595 a jedným číslom daru, a to 1555. Dve hlavice z nich boli objavené v župe Suceava v rámci rumunskej Bukoviny a Moldavska - hlavice sekier z Fântâna Mare (inv. č. 178595) a Suceava (inv. č. 72492), jedna hlavica v župe Ilfov v rámci Valašska - hlavica sekery z Balta Neagră (č. daru 1555), a posledná hlavica sekery je uložená v MNIR bez špecifikácie jej nálezového kontextu pod inventárnym číslom 37793 (obr. 1). Každý z vyššie spomenutých exemplárov má špecifický tvar a zdobenie. Okrem hlavice sekery z Fântâna Mare (Bătrîna/Monoranu/Bătrîna 1984, 172, obr. 5: 1) nebol zvyšok skúmanej kolekcie dosial publikovaný. Avšak treba pripomenút, že exemplár z Fântâna Mare nebol taktiež zhodnotený v súvislosti s jeho tvarom a dekoráciou.

Hlavica sekery širočiny s číslom daru 1555 (obr. 2: 1) bola v roku 2015 nájdená ako ojedinelý nález v priestore neznámeho lesa pri obci Balta Neagră, v rámci komúny Nuci. Pokial’ sa to týka tvarových analógií ostria, tela a kŕčku danej hlavice z profilu, je možné uvažovat’ aj o jej včasno- a vrcholnostredovekom datovaní. Dané analógie sú symetrické zvrchu i zospodu, opatrené ostňami a väčšinou aj s obuchom. Takéto prvky posudzovaná hlavica ale postráda. Keby ich však mala, mohla by patrit k typu hlavíc sekier nazvaného Lunow, ktorý vieme datovat väčšinou do druhej polovice 10. a prvej polovice 11. stor. (napr. obr. 3: 1, 2; Michalak/Kotowicz 2014, 107, 110-112, obr. 5-7). Exempláre tohto typu sa našli v Dánsku, Nemecku, Pol’sku, Kaliningradskej oblasti Ruska a vo Švédsku.

Niet však pochýb, že asymetrický tvar skúmanej hlavice zvrchu i zospodu a jeho razená/kolkovaná výzdoba poukazujú na obdobie vrcholného/neskorého stredoveku a včasného novoveku v Európe. Rôzne tvarované hlavice sekier, avšak odlišné od hlavice z Balta Neagră, boli ale rovnako zdobené. Objavovali sa na nich tiež razené kombinované línie a body/krúžky/polmesiace, ktoré sa razili väčšinou v podobe vetvičiek alebo troch radiálne zbiehajúcich sa línií s bodmi/kruhmi/polmesiacmi na ich koncoch. Pri spomínaných vetvičkách vieme o niekolkých paralelách hlavíc sekier zo súčasného Rumunska, Pol’ska a Českej republiky (obr. 4: 1, 2; 5: 1, 2; Croitoru 2016, 337, obr. 4; Dejan/Ilie 2017, 113, obrázok na strane 113; Głosek 1996, 94, tab. XVI: C; Ilie/Dejan 2018, 197, obrázok na strane 197; Měchurová 2013, 627, obr. 5), ktoré boli datované do 13. až 17. stor. Niektorí bádatelia pokračovanie takejto výzdoby posúvajú až do súčasnosti (Měchurová 2013, 627, 628). Zdobenie razenými vetvičkami vieme identifikovat’ aj pri zbrani zvanej táborová sekera (v angličtine doloir/wagoner's axe), ktorá sa takto zdobená objavovala v západnej a strednej Európe v 15. až 17. stor. (napr. obr. 5: 3; Marek 2008, 128-130, obr. 175: e-f; Zdaniewicz 2016, 269, obr. 2-5).

Na hlavici sekery z Balta Neagră sa objavila i výzdoba v podobe razených ozubených kriviek s vystupujúcimi polkrúžkami. Podobné, no s vystupujúcimi trojuholníčkami, môžeme pozorovat’ aj na skúmanej hlavici sekery z Fântâna Mare (obr. 6: 1; Bătrîna/Monoranu/Bătrîna 1984, 165, 172, 174, obr. 5: 1), ktorá sa dá datovat’ do 15. stor. Ozubené razené krivky s vystupujúcimi polkrúžkami sú ale na jednej dvojsečnej zbrani/pomôcke zo Slovenského národného múzea v Martine (obr. 7; Pivková 2016, 60-62, obr. 41, 42). Hoci ju A. Pivková $(2016,62)$ datovala na základe analógií k jej čepeli do konca 14. až začiatku 16. stor., súčasný nepublikovaný výskum poukazuje skôr na neskoršie obdobie novoveku 18.-19. stor. (?; Žákovský $2014 a, 176,177)$.

Ďalším exemplárom z posudzovanej zbierky je hlavica sekery (obr. 6: 1) nájdená v roku $1982 \mathrm{v}$ priestore súkromnej feudálnej kaplnky vo Fântâna Mare (inv. č. 178595), konkrétne vo vrstve náležiacej k prvej fáze jej využívania. Tým pádom môžeme túto čast̉ zbrane zaradit’ do 15. stor. (Bătrîna/Monoranu/Bătrîna 1984, 165, 172, 174, fig. 5: 1). Masívna hlavica sekery má skosenú bradu a je zdobená razenou dekoráciou v podobe ozubených línií vytvárajúcich rôzne cik-cakovité, krížové, vetvičkové a radiálne vzory. Dané ozubené línie sa skladajú z línií a trojuholníčkov vychádzajúcich z ich jednej strany.

Tvarovo sa najviac ponáša na podtyp VIIIa, ktorý vyčlenil M. Głosek v rámci typológie neskorostredovekých hlavíc sekier z Pol'ska. Uvedený bádatel' ho datoval od druhej polovice 13. do 16. stor. (napr. obr. 6: 2; Głosek 1996, 39, 40, 80, 99, 
tab. IV; XV-XVI). Najbližšie analógie k dekorácii môžeme vidiet’ už vo vyššie spomínanej novovekej zbrani/pomôcke zo Slovenského národného múzea v Martine (obr. 7; Pivková 2016, 60-62, obr. 41, 42) alebo včasnonovovekej hlavici sekery z Valea Mărului v rumunskej župe Galați (obr. 4: 1; Croitoru 2016, 337, obr. 4). V prvom prípade ide o ozubenú razbu, pri ktorej sú na línie pripojené razené polkrúžky a v druhom prípade ide snád’ len o bodovú razbu.

Pod inventárnym ćíslom 72492 sa v MNIR vedie hlavica sekery z neznámej lokality v rámci katastrálneho územia Suceava, ktorú toto múzeum získalo v roku 1975. Vyznačuje sa najmä hrotitou bradou a kolkovanou výzdobou v tvare štvorlístka na jednej strane jej kŕčku (obr. 8: 1). Jej tvarové paralely z priestoru strednej Európy a Rumunska môžeme datovat' do 13. až 16. stor. (napr. obr. 8: 2; Głosek 1990, 138, 502, obr. 22; 1996, 40, 42, 80, tab. IV; XVII-XX). Skoro tvarovo identická hlavica a s rovnakou kolkovanou výzdobou sa našla v rieke Váh pri Moravanoch nad Váhom-Hubine (obr. 8: 3; Klčo 1988, 76, obr. 16) a podobnú razbu má aj hlavica z Baia Mare (obr. 9: 1; Emandi 1981b, obr. 22: 2) v rumunskej župe Maramureș. Tieto exempláre boli archeológmi zaradené do 15. až 16. stor.

Poslednou skúmanou sekerou je sekera z neznámej lokality uložená v MNIR od roku 1975. Jej inventárne číslo je 37793 (obr. 10). Je typická poriskom, ktoré je zdobené 10 hlavičkami klincov zo žltého neželezného kovu, d’alej hlavicou zdobenou v priestore jej ostria a tela devätnásobným krúžkovým perforovaním usporiadaným v kruhu a šestimi konkávnymi výrezmi v rovnakom priestore. K tomu treba ešte prirátat pomerne dlhý kŕčik danej hlavice a konvexne vyhnuté ostrie. K uvedenej sekere neexistuje priama analógia, no jej prvky môžeme nájst’ v prípade jej súčasných sekier, halapartní, gizarm, berdyš a loveckých kopijí.

Vd’aka konvexne vyhnutým ostriam, konkávnym výsekom a prítomnostou rôzneho perforovania sú najbližšími analógiami k posudzovanej sekere tri berdyše z Rumunska, Pol'ska a Ukrajiny, ktoré je možné datovat’ od druhej polovice 15. do 17. stor. (napr. obr. 11: 1, 2; Czyżewski 2013, 235-237, 409, obrázky na strane 235-237, 409; Terskyj 2005, 21, 23, 24, obr. 4: 18). Ďalšie relevantné paralely sa týkajú devätnásobného krúžkového perforovania tela a čepele zbrane, ktoré je usporiadané v kruhu. Tieto halapartne a gizarma zo zbierok múzeí západnej, strednej a severnej Európy bádatelia zaradili do 16. až začiatku 17. stor. (obr. 12: 1-3; 13: 1; Boeheim 1890, 337, 341, obr. 392: c; 394; Demmin 1893, 825, 826, obr. 13; Waldman 2005, 166, 167, obr. 135). Ostatné paralely viažuce sa na konkávne výseky vieme pozorovat na zbraniach a v ikonografických prameňoch severnej, strednej a východnej Európy v období 15. až 17. stor. (napr. obr. 14: 1, 2; Boeheim 1890, 338, 341, 372, obr. 392: e-f; 395; 440, 441; Demmin 1893, 818, 819, 825, 826, obr. 5; 8; 11; Kalmár 1971, 33, 39, obr.; Oakeshott 2000, 50, obr. 9: B-C; Radziwiłł Chronicle; Stone 1961, 111, obr. 142: 2-4; Waldman 2005, 157, obr. 126). Nakoniec značku výrobcu, ktorá sa v podobe lipového lista a konára možno objavuje na kŕčku posudzovanej sekery, nachádzame aj na dvoch bojových kopijách v loveckom štýle, pravdepodobne datovaných do včasného 16. stor., ktoré sú uložené v londýnskom Toweri (Ffoulkes 1916, 221, 488, značky výrobcov 54, 56, Appendix B: 170-171).

Záverom treba uviest’ ešte pár postrehov týkajúcich sa datovania a funkčného využitia skúmaných predmetov. Exempláre z Balta Neagră a Suceava môžu byt pravdepodobne chápané aj ako najstaršie predmety v skúmanom súbore. Mohli byt๋ vyrobené už v 13. stor. (Balta Neagră) a na konci tohto storočia, či až v 15. stor. (Suceava). Výroba hlavice zo Suceava mohla byt’ najneskôr uskutočnená v 16. stor., no hlavica z Balta Neagră mohla byt๋ vytvorená v 17. stor. alebo v priebehu včasného novoveku. Nálezový kontext exemplára z Fântâna Mare nám ho jasne umožňuje datovat’ do 15. stor. Najmladšou posudzovanou hlavicou sekery môže byt’ exemplár vedený v MNIR pod inventárnym číslom 37793, ktorý je datovaný od 15./16. stor. až do 17. stor.

Niektoré z pojednávaných múzejných zbierkových predmetov môžeme považovat' za nástroje a niektoré zase za zbrane. Hlavica sekery z Balta Neagră a možno aj hlavica sekery z Fântâna Mare mohli byt’ najpravdepodobnejšie používané ako súčasti nástrojov na opracovanie dreva. Exemplár zo Suceava a možno i ten z Fântâna Mare by sa mohli používat’ aj ako sekery s univerzálnym použitím. Sekera s inventárnym číslom 37793 bola najpravdepodobnejšie určená na použitie v boji.

Obr. 1. Náleziská zdobených stredovekých a včasnonovovekých sekier z Národného múzea rumunskej histórie v Bukurešti (RO). 1 - Balta Neagră (Župa Ilfov, RO), č. daru 1555 v MNIR; 2 - Fântâna Mare (Župa Suceava, RO), inv. č. 178595 v MNIR; 3 - Suceava (Župa Suceava, RO), inv. č. 72492 v MNIR; 4 - neznáme nálezisko/Národné múzeum rumunskej histórie v Bukurešti, inv. č. 37793. Autor distribučnej mapy M. Husár. Mapový podklad Google My Maps.

Obr. 2. Skúmaná stredoveká a včasnonovoveká hlavica sekery z Balta Neagră (župa Ilfov, RO, ojedinelý nález, č. daru 1555, 13.-17. stor./včasný novovek) deponovaná v Národnom múzeu rumunskej histórie v Bukurešti (RO). a-d kresby G. Ducman; e - fotografia T. A. Martina; f - fotografia M. Husára. Všetko železo. Mierka: a - a-c; e-f; b - d.

Obr. 3. Analógie prvkov skúmanej stredovekej a včasnonovovekej hlavice sekery z Balta Neagră (č. daru 1555) deponovaná v Národnom múzeu rumunskej histórie v Bukurešti (RO). 1 - Archeologické múzeum v Krakove, druhá polovica 10. a prvá polovica 11. stor. (podla datovania hlavíc sekier typu Lunow; PL, podla Kotowicz 2011, obr. 5: 6; Michalak/Kotowicz 2014, 115, obr. 7: 6); 2 - Národné múzeum v Štetíne, druhá polovica 10. a prvá polovica 11. stor. (podla datovania hlavíc sekier typu Lunow; PL, podl’a Kotowicz 2014, tab. CLXVII: 4; Michalak/Kotowicz 2014, 115, obr. 7: 8).Všetko železo.

Obr. 4. Analógie prvkov skúmanej stredovekej a včasnonovovekej hlavice sekery z Balta Neagră (č. daru 1555) deponovaná v Národnom múzeu rumunskej histórie v Bukurešti (RO). 1 - Valea Mărului, ojedinelý nález, po polovici druhého tisícročia n. 1. (Župa Galați, RO; podla Croitoru 2016, obr. 4: 1); 2 - Konůvky, pevnosṫ, po prvú polovicu 15. stor. (CZ, podla Měchurová 2013, 627, obr. 5). Všetko železo.

Obr. 5. Analógie prvkov skúmanej stredovekej a včasnonovovekej hlavice sekery z Balta Neagră (č. daru 1555) deponovanej v Národnom múzeu rumunskej histórie v Bukurešti (RO). 1 - Curtea Domnească de la Vaslui, sídlisko, dom L 11 (sekcia S III), druhá polovica 15. stor. (RO, podla Dejan/Ilie 2017, 113, obr. na str. 113; Ilie/Dejan 2018, 197, obr. na str. 197); 2 - neznáme nálezisko, nejasný nálezový kontext, 13.-16. stor. (?; podla Głosek 1996, 94, tab. XVI: C); 3 - Toszek, 
nejasný nálezový kontext, 15.-16. stor., možno 17. stor. (PL; podl’a Zdaniewicz 2016, 269, obr. 2-5). Všetko železo. Mierka: $\mathrm{a}-1,2 ; \mathrm{b}-3$.

Obr. 6. Skúmaná stredoveká a včasnonovoveká hlavica sekery z Fântâna Mare (inv. č. 178595) deponovaná v Národnom múzeu rumunskej histórie v Bukurešti $(\mathrm{RO})$ a analógie k jej prvkom. 1 - Fântâna Mare, ojedinelý nález z priestoru kaplnky, 15. stor. (Župa Suceava, RO; inv. č. 178595 v MNIR; kresby a fotografie M. Husára); 2 - Radymno, vodný nález, 13. stor.? (PL; podla Głosek 1996, 90, tab. XV: F). Všetko železo.

Obr. 7. Dvojsečná zbraň alebo pomôcka z neznámeho náleziska deponovaná v SNM v Martine (nejasný nálezový kontext, inv. č. KH5955, 18.-19. stor. (?); fotografia a obrázok podl’a Pivková 2016, 62, obr. 41; 42). Všetko železo. Mierka: $\mathrm{a}-\mathrm{a} ; \mathrm{b}-\mathrm{b}$.

Obr. 8. Skúmaná stredoveká a včasnonovoveká hlavica sekery zo Suceavy (inv. č. 72492) deponovaná v Národnom múzeu rumunskej histórie v Bukurešti (RO) a analógie k jej prvkom. 1 - Suceava, nejasný nálezový kontext, koniec 13. stor./15. stor. až 16. stor. (Župa Suceava, RO, inv. č. 72492 v MNIR; kresby a fotografia M. Husára); 2 - Siedlątków, ojedinelý nález z priestoru hradu, okolo roku 1380 (PL; podla Głosek 1990, 138, 502, obr. 22); 3 - Moravany nad Váhom-Hubina, vodný nález, polovica 16. stor. (SK; podl’a Klčo 1988, 76, obr. 16). Všetko železo.

Obr. 9. Analógie prvkov skúmanej stredovekej a včasnonovovekej hlavice sekery zo Suceavy (inv. č. 72492) deponovanej v Národnom múzeu rumunskej histórie v Bukurešti (RO). 1 - Baia Mare, 15.-16. stor. (Župa Maramureș, RO, podla Emandi 1981b, obr. 22: 2); 2 - Baia Mare, 15.-16. stor. (Župa Maramureș, RO, podla Emandi 1981b, obr. 22: 5). Všetko železo.

Obr. 10. Skúmaná stredoveká a včasnonovoveká sekera (neznáme nálezisko, inv. č. 37793, 15./16.-17. stor.) z Národného múzea rumunskej histórie v Bukurešti (RO). a, b, d - kresby G. Ducman; c, e - kresba a fotografia M. Husára. a, c železo; b, d-e - železo, neželezný žltý kov, drevo. Mierka: a - a-b, d-e; b-c.

Obr. 11. Analógie prvkov skúmanej stredovekej a včasnonovovekej sekery (inv. č. 37793) z Národného múzea rumunskej histórie v Bukurešti (RO). 1 - Královský hrad Wawel v Krakove (PL?), inv. č. dep. 2573, 17. stor. (podl’a Czyżezwski 2013, 235-237, 409, obr. na str. 235-237, 409); 2 - L'vovské historické múzeum (Lvov?), inv. č. 3-3532, 16. -17. stor. (podl’a Terskyj 2005, 21, 23, 24, obr. 4: 18). 1 - železo, drevo; 2 - železo.

Obr. 12. Analógie prvkov skúmanej stredovekej a včasnonovovekej sekery (inv. č. 37793) z Národného múzea rumunskej histórie v Bukurešti (RO). 1 - Dánske vojenské múzeum v Kodani (RF?), inv. č. C50, rok 1530 (podla Waldman 2005, 166, 167, obr. 135); 2 - zbierka Verfaffer (CH?), polovica 16. stor. (podla Demmin 1893, 825, 826, obr. 13); 3 - zbierka Van Zuylen (NL?), začiatok 17. stor. (podla Boeheim 1890, 337, obr. 392: c). 1 - železo, mosadz, drevo; 2, 3 - pravdepodobne železo a drevo. Bez mierky.

Obr. 13. Analógie prvkov skúmanej stredovekej a včasnonovovekej sekery (inv. č. 37793) z Národného múzea rumunskej histórie v Bukurešti (RO). 1 - zbrojnica hohenzollernovského paláca v Sigmaringen (DE?), koniec 16. stor. (podla Boeheim 1890, 341, obr. 394); 2 - neznáma zbierka i nálezisko (IT), 17. stor. (podla Boeheim 1890, 338, obr. 392: e). Pravdepodobne železo a drevo. Bez mierky.

Obr. 14. Analógie prvkov skúmanej stredovekej a včasnonovovekej sekery (inv. č. 37793) z Národného múzea rumunskej histórie v Bukurešti (RO). Ilustrácie Radzivilskej kroniky; 15. stor. (podla Radziwiłł Chronicle).

Tabela 1. Rozmery a váhy skúmaných stredovekých a včasnonovovekých sekier z Národného múzea rumunskej histórie v Bukurešti (RO).

Mgr. Martin Husár, PhD.

Univerzita Konštantína Filozofa v Nitre

Filozofická fakulta

Ústav pre výskum kultúrneho dedičstva Konštantína a Metoda

Trieda A. Hlinku 1

SK - 94974 Nitra

mhusar@ukf.sk

Ph. Dr. Silviu Ion Oța

Muzeul Național de Istorie a României

Secția de Arheologie Pre și Protoistorică, Clasică, Medievală și Preventivă

Calea Victoriei 12

Sector 3

$\mathrm{RO}$ - 030026 București

silviuota@yahoo.com

Tudor Alexandru Martin, MA

Muzeul Național de Istorie a României

Secția Cabinet Numismatic și Tezaurul Istoric

Calea Victoriei 12

Sector 3

RO - 030026 București

green_yuri_13@yahoo.com 